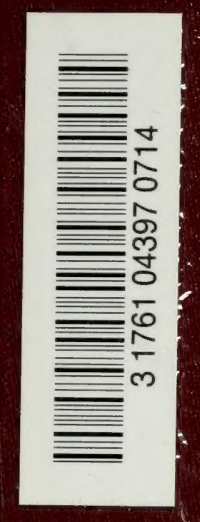

OK

495

C7565

c.2

BMED 
Digitized by the Internet Archive in 2008 with funding from Microsoft Corporation 




\section{ELEMENTARY NOTES ON CONIFERS}

By

A. H. CHURCH, M.A.

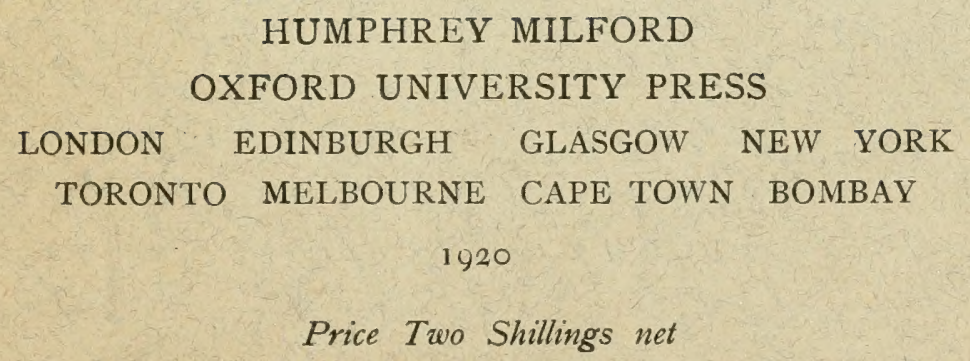



TANICAL MEMOIRS. No. 8

\title{
ELEMENTARY NOTES ON CONIFERS
}

\author{
thing By \\ A. H. CHURCH, M.A.
}

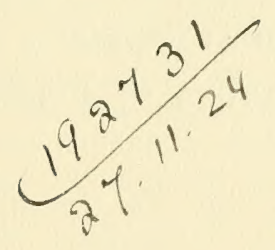

\footnotetext{
HUMPHREY MILFORD

OXFORD UNIVERSITY PRESS

LONDON EDINBURGH GLASGOW NEW YORK

TORONTO MELBOURNE CAPE TOWN BOMBAY 


\section{QK 495 \\ $C 75 C 5$ \\ Cop, 2}

\section{CONTENTS}

PAGE

I. LAND Flora (Bryophyta, Pteridophyta) . . . . 3

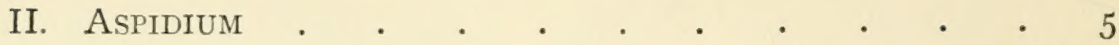

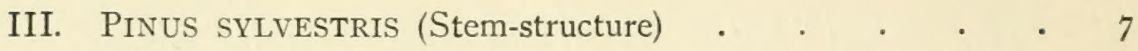

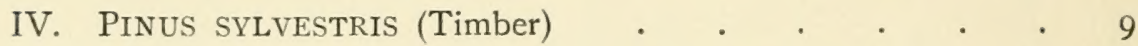

V. Pinus sylvestris (Leaf) .

VI. Pinus sylvestris (Reproduction) . . . . . . I3

VII. PINUS (Genus) . . . . . . . . . . .

VIII. Cedrus, Larix • c .

iX. Picea, Tsuga, Pseudotsuga, Abies * * • .

X. TAxodineae . . . . . . . . . . $2 \mathrm{I}$

XI. Cupressineae (Cupressus, Chamaecyparis) • . $\quad{ }^{2} 3$

XiI. Thuya, Biota, Juniperus . . . . . . . 25

XiII. Araucarineae . . . . . . . . . 27

XIV. Taxus : Ginkgo . . . . . . . . . . 29

XV. Anatomy of Foliage-Leaves . . . . . . 3I

These notes have been put together for the use of classes of Forestry students (1919-20), and are collected as following a condensed course of lectures and practical work in continuation of the series outlined in previous memoirs (Nos. 4, 5, 7).

Botanic Garden, OxFord,

July 1920. 
LAND FLORA: as constituting the autotrophic vegetation of subaerial environment (beyond the horizon of saprophytic phyla of Fungi), expresses the progression of plant-life from the medium of water to that of atmosphere; involving not only the factor of diminishing water-supply (ultimately reduced to a vanishing point), but more definitely that of nutrition in terms of food-salts no longer available in the general medium, and implying the mechanism of absorption, conduction, and transpiration.

Older phases of sexual reproduction, involving fertilization by mobile gametes in a watery medium, are long retained; but dispersal is provided for by the evolution of wind-borne spores, in a manner paralleling that of many subaerial Fungi, as spores produced in a sporangium.

Three main lines of advance, roughly indicated as (I) Bryophyta (Mosses), (2) Pteridophyta (Ferns), (3) Phanerogams (Seed Plants), not necessarily in linear sequence, are to be regarded as parallel phases of progression, passing successively to higher stages of land-organization.

BRYOPHYTA, including Mosses (Bryineae), with Liverworts (Hepaticae) and Jungermanniae: one general plan of organization and life-cycle common to all, and the plant-types of no great size or importance: Sphagmum, the Bog-Moss, alone attains special economic and geographical significance.

The Life-cycle presents a definite alternation of generations, in which the sexual phase is still dominant, as the individual receiving the name, and is attached to the substratum by rhizoids, absorbing freely over its entire surface; hence requiring a saturated atmosphere, or copious atmospheric precipitations.

The sexual organs are antheridia $\left(\sigma^{7}\right)$ and archegonia $(q)$; the flagellated antherozoids are 2 -ciliated; the oosphere is solitary in the venter of the archegonium, and is fertilized in situ. The zygote (oospore) develops directly to a parasitic sporophytic phase, which remains permanently attached to the gametophyte, being wholly dependent on it for water-supply, and reducing to a simple capsule-like body (sporogonium), more or less stalked, and devoted to the production of air-borne spores: the latter are produced in great numbers, in tetrad-groups following a stage of meiosis.

All the types are more or less decadent, and may be regarded as vestigial relics, restricted to distinctly inferior biological stations; e. g. mosses on walls or in shady hedges, on peaty soil, among grass, on the bark of trees, especially in tropical rainforests : from the standpoint of higher vegetation an indication of inferior or ill-drained soil. The more familiar and more striking types include :-

I. Polytrichum commune, a large tussock-form, the shoots of the gametophyte growing in close association, a foot high or more, and bearing short acute leaves in spiral sequence. The apex is controlled by a 3 -sided apical cell, each segment from which produces a leaf: the leaf-laminae bear plates of protosynthetic tissue on their upper surface, and the growing-point is enclosed in a bud-aggregate. Archegonia and antheridia are produced in spring at the apices of special shoots, the latter in lateral groups in leaf-axils. Fertilization effected in rain-water (May); the embryo grows in the enlarged archegonial cavity, taking up a portion of it with shaggy hair-growth as calyptra, and elongating to a stalk (seta), 2-3 in. long, and a radially symmetrical capsule $(7 \mathrm{~mm}$.): the latter differentiates a wall, air-spaces, archesporium, columella, \&c.; an apophysis-region with stomata, intercellular spaces, cuticle, implies a transpiration-mechanism. The archesporium gives rise to sporetetrads, and finally spores, ro $\mu$ diam. ; the apex differentiates a conical operculum which is shed to expose the peristome-region of teeth and epiphragm, constituting a sprinkling-mechanism for wind-dispersal of the spores. The latter germinate on damp ground to give a filamentous Protonema-stage, from which leafy shoots are produced as buds, differentiating a 3 -sided apical cell and parenchymatous organization. Note. The sporogonium is haustorial, and so initiates a transpiration current, but there is no direct absorption from the soil solutions.

II. Funaria hygrometrica, a small Moss-type, on walls or unoccupied burnt ground, I-2 in. high only: the gametophyte is a mere rosette of leaf-laminae, I cell thick, with mid-rib; apical growth by 3 -sided cell. Antheridia and archegonia are borne on separate plants, in terminal sori only; archegonia $200 \mu$ long, and oosphere 
Io $\mu$ diam.; antherozoid with 2 equal flagella. Fertilization in casual drops of water at any season (ephemeral). Sporophyte as a pear-shaped capsule $(3-4 \mathrm{~mm}$.) on a slender seta presenting hygrometric curvatures, with a membranous calyptra; the apophysis differentiates stomatal mechanism, the capsule a wall, air-space, and archesporium, the latter giving rise to spores, matured at $20 \mu$ diam. The Peristome is complex of $16+16$ 'teeth', exposed by the abscission of the operculum ( $1 \mathrm{~mm}$.) to constitute a grille for gradual wind-dispersal. The Protonemal juvenile stage may multiply by gemmae.

Marchantia polymorpha: a typical Liverwort on damp light soil in spring. Gametophyte a dorsiventral dichotomously lobed thallus with apical cell ( 2 sided), rhizoids on lower surface and areolate chambers on upper. Vegetative propagation by gemmae produced in 'cups'. Antheridia and archegonia borne on special erected shoot-systems, dioecious; fertilization in casual water. The zygote gives a small capsule $(\mathrm{I} \mathrm{mm}$.) ; many such being formed on the under surface of the umbrella-like female 'receptacle'. Sporophyte of short stalk $(2 \mathrm{~mm}$.) and capsule of wall and spore-mass with elaters, dehiscing irregularly at apex. Protonema stage ill-defined.

Cf. also Lumularia, Fegatella (Hepaticae), Pellia, Frullania (Jungermanniae).

PTERIDOPHYTA : including the great Fern-series (Filicineae), Horse-tails (Equisetineae) and Club-mosses (Lycopodineae with Selaginella), a group of very distinct phyla now left at a common horizon, in which-

The gametophyte is reduced to a vestigial leafless prothallus, in the general case still green and autotrophic, bearing few antheridia and archegonia, the former producing flagellated antherozoids (multiciliate in Ferns and Equiseta, biciliate in Lycopods and Selaginella). Fertilization of the oosphere of archegonium in casual water-supply of rain or dew; the plant vegetating only in a saturated atmosphere, normally short-lived, but sexually efficient.

On the other hand, the sporophyte acquires great size and differentiation as a land-plant, receiving the recognized name, and becoming an independent organism by the elaboration of roots absorbing directly from the soil; in correlation with this the transpiration-current is more effective, and vascular tissues (xylem with tracheides) are initiated as special conduction-mechanism for a transpiration-current. The stem is erect, radially symmetrical with leaves in phyllotaxis (spiral or whorled), and apical growth is controlled by a 3 -sided apical cell, or massive meristem (Lycopods).

Asexual sporangia are borne on special leaves (sporophylls), and produce spores, again formed in meiotic tetrads, to be discharged by the dehiscence of the sporangia in air, wind-borne, $3^{\circ} \mu$ diam. or so, and directly comparable with the pollen-grains of Angiosperms.

The sporophyte bearing foliage-leaves thus attains the general characteristics of a 'land-plant', while the sexual phase is vestigial, still essentially alga-like and aquatic.

The existing main phyla are distinguished by special departures as the lineal descendants of similar organism traced back to the Carboniferous Epoch, and beyond, as plants of even arboreal habit, growing in forest-association, and constituting the bulk of the coal-beds (Calamodendron, Lepidodendron, Sigillaria). At the present time the types are restricted to inferior biological stations (shade-plants, xerophytes, aquatics); cf.: Filicineae of damp woodland and shaded base of warm forest-association.

Equisetineae of swamps, Lycopods of hill-pastures, and as tropical epiphytes, Selaginella as forest undergrowth.

Filicineae are usually distinguished by large compound leaves, up to $3 \circ \mathrm{ft}$. in Tree-ferns, to the D.V. subterranean rhizome of Pteris (Bracken), sending up I compound leaf each season. Sporangia normally on under-surface of the leaves; special types characteristic of main groups. Heterospory obtains in small reduced aquatic forms as Salvinia, Azolla, Pilularia.

Equisetineae, with no leaves beyond rudiments as 'teeth', whorled branchsystems with marked nodes and internodes; terminal strobili of special sporophylls, often on special shoots in spring, finest in E. Telmateia.

Lycopods, axes dichotomously branched, leaves small and scale-like, xerophytic habit; sporophylls in spicate strobili, one sporangium per sporophyll, on the upper surface only. Selaginella essentially similar, but typically D. V. shoot-systems, with radial strobili bearing sporangia and spores differentiated as micro- and mega-forms, often in the same strobilus; the megasporangium reduced to one tetrad of 4 large spores. 
ASPIDIUM FILIX-MAS (Nephrodium) 'Male-Fern': Indigenous ferntype of damp under-wood; massive rhizome obliquely erected, or prostrate at surfacelevel, with crown of bipinnate Foliage-leaves each season, 3-4 ft. or more long, $8-13$, in spiral series $(3: 5)$; primary pinnules $40-50$ each side of main rachis, 6 in. long, diminishing distally; secondary pinnules $20-30$, half an inch long, diminishing distally, decurrent below and serrated. Sporangia borne in sori on lower surface of pinnules (June), in rows of 4-5 on either side of midrib, fewer distally on all ramifications. Sorus with kidney-shaped, umbrella-like indusium, $2 \mathrm{~mm}$. diam., covering sporangia when young: sporangia 100 or more, formed indefinitely from placental cushion-growth, supplied by end of v.b.

Spcrangia, ovoid, compressed, $25^{0-275 \mu}$ long, on slender stalks $\left(\frac{1}{2} \mathrm{~mm}\right.$.) of 3 rows of cells: wall of one layer; annulus-crest for $\frac{3}{4}$ of periphery, of $15-18$ cells with U-thickening ( $1 \circ \mu$ ), coloured golden-brown when adult; 'lip-cells', and dehiscence-mechanism of living cells: archesporium, tapetal layers (2 deep), sporemother cells, tetrads $(\mathrm{I} 6 \times 4=64)$; average production dependent on nutrition (48). Spores with brown cuticularized exospore, $50 \mu$ diam., kidney-shaped, with granulated surface. Output, at a moderate estimate ( 10 fronds, $5 \circ$ pinnules, 30 secondary, Io sori, I00 sporangia, 48 spores) $=720$ million (possibly 1,000 in a fine plant) per annum,

Prothallus (= Gametophyte): Germination of spore to cell-filament with chloroplasts; broadening to bilateral lamina, I cell thick, to adult-form $(3-5 \mathrm{~mm}$.), heart-shaped, with growing-point of small cells in 'notch'; median cushion, D.V. organization, rhizoids and reproductive organs on lower surface. Antheridia scattered, sub-globular outgrowths $(5 \circ \mu$ diam.); wall of 2 ring-cells, lid-cell, and central spermatocyte tissue : antherozoids about 16 , liberated as motile zoìds, spiral of 2-3 coils, flagellae on anterior half, multiciliate; about $3 \circ \mu$ long when straightened out. Chemotactic attraction (malic acid) and fertilization. Archegonia, few, shortlived, continuously produced behind notch, on central many-layered cushion only (10-100), until fertilization is effected for one; half-sunk, venter ill-defined, neck of 4 rows, $4-5$ cells $(100 \mu)$; dehiscence by 4 lip-cells; central series of neck-cell (coenocytic), ventral canal-cell, oosphere $(40 \mu$ diam.). Fertilization as fusion of gamete-nuclei only, to diploid zygote (= oospore). 'Germination' immediate; octant-segmentation; differentiation of regions to give the embryonic-

Sporophyte as a land-organism: emergence of cotyledon (first leaf), with dichotomous ramification, from distended archegonium; growth of first root ; differentiation of shoot-apex, and apical cells; haustorial 'foot'-region, parasitic on enlarged prothallus ( $10 \mathrm{~mm}$.): independence gained with water-absorption by root: erected axis with 3 -sided apical cell; juvenile leaves with increasing differentiation; development of bipinnate frond ('megalophylly'). Structure of main axis in terms of dictyostele; no secondary thickening: development of leaves in phyllotaxispattern $(3: 5)$ independently of apical cell-segmentation. Root-system wholly adventitious, from massive leaf-bases. No internodal extension in main axis. Leafpinnules spaced in leaf-mosaic, as D.V. system; circinnate vernation; leaf-system seasonal, but not 'deciduous': age indefinite; rhizome with occasional branching, giving connected shoots with annual crowns; but the whole clearly reduced from erect tree-fern model ( $30-60 \mathrm{ft}$. stem).

Note, 'Alternation of Generations', Haploid and Diploid phases, Life-Cycle.

I. The Sporophyte as land-vegetation, sub-aerial, with intercellular spaces, cuticle, stomata, and transpiration-system; involving vascular supply (xylem), and absorptive root. Production of air-dry, wind-borne spores (homosporous), all alike; wastage-coefficient enormous : chances of germination of spores in hot summer (July) practically nil. Hence restriction to damp situations, as shade-vegetation, and regions with more ample rainfall.

II. The Gametophyte, a reduced, highly-specialized, and vestigial relic of the aquatic phase (algal and benthic); short-lived, precociously reproductive, with no transpiration-mechanism : reproductive organs as much-reduced structures; output of antherozoids - $\mathrm{a}$ few hundred may be sufficient; output of oospheres still smaller: wastage of sexual process extremely small, correlated with small size, and efficiency 
of the sexual plant, given casual water-supply by condensation of a saturated atmosphere.

III. Motile Antherozoid as retention of flagellated phase of still older planktonhabit. Motility of oosphere lost, consequent on advanced oogamy, and fertilization in situ (no longer discharged).

Note, no other land-plant so conveniently expresses the independent existence of these 3 phases, as epitomizing and 'recapitulating' the history of 3 epochs of worldvegetation. Thus the Moss never attains the independence of a land-plant with roots; Selaginclla has lost the free-living (autotrophic) prothallus; as has also Ginkgo with the culminating tree-habit.

Pteris Aquilina (Bracken), indigenous and cosmopolitan, more significant as unit of vegetation, clothing hill-sides, in pure association; also in woodland shadehabit. Highly specialized sporophyte phase: Rhizome, subterranean (for protection), dorsiventral in construction and ramification; $10-20 \mathrm{~mm}$. diam., with internodes elongated (several inches). Foliage-leaves, 2-6 ft., erect, one per shoot-apex, seasonal, with 4-year period. Fronds 3 times pinnated, more or less tripartite; ultimate lobes coriaceous, with reflexed margins; hydathode-glands at base of main segments ; vasc. system in characteristic D.V. pattern in section. Sporangia along entire course of marginal vein, with membranous indusial overlap of leaf-margin. Details as in Aspidium; wastage-coefficient at least as large. Prothallus similar : differences only noted in biological adaptations of sporophyte and their consequences: propagation on exposed hill-sides wholly by vegetative growth.

SELAGINELLA (700). Type of Heterosporous Lycopodineae; tropical and sub-tropical; So sfinosa alone indig.: Selaginella inaequalifolia (Hort.), Himalya : Shoot-system, sub-erect, 3-4 ft. long, with D.V. frondose habit; repeatedly divided, in lateral systems, up to $6 \mathrm{in}$. ; leaves, small, decussate, in 4 rows, as a diagonally orientated, eccentric decussate system; smaller upper leaves ( $\mathrm{r} \mathrm{mm}$.), larger flanking leaves ( $2 \mathrm{~mm}$.), in symmetrical mosaic (cf. Cupressius).

Ends of shoots erected, 4-angled and 4-rowed strobiti ( $\frac{1}{2}$ in. long), in which sporophylls are differentiated; majority with microsporangia ; a few, towards base, as megasporangia. Microsporangia in axil of leaf, kidney-shaped, with indefinite tetrads of microspores, $3 \circ \mu$ long, orange-brown; output 4-5,000; Negasporangia, larger $(.8 \mathrm{~mm}$.), with one tetrad of 4 large white megaspores $(300 \mu)$. Ratio of Heterospory, by number, approx. I,000: I ; by volume, I : I,000.

Germination of spores independently in casual moisture; microspores to small prothallus, minute, non-autotrophic, no larger than spore; producing 4 biflagellated antherozoids only: Megaspore germinating inside ruptured spore-coat, to tissue without chlorophyll, at expense of reserves only, and producing a few archegonia, sunk in tissue at exposed end. Fertilization in casual water-supply; embryo at first parasitic on food-reserves, with 'suspensor'-mechanism.

Theory of Megaspore: In the ancestral algal phase of the sea sexual reproduction, by fusion of 'gametes', was perfected in advancing stages of physiological differentiation from $(\alpha)$ Isogamy (equal gametes), to $(\beta)$ a distinction of 'male' and 'female' (Heterogamy); to $(\gamma)$ one large rounded oosphere (Oogamy), and ultimately this failed to be discharged, and is henceforward $(\delta)$ ' Fertilized in situ'.

In emergent Land Flora a very similar progression is presented in the case of wind-borne asexual spores. At first all alike, (a) Homospory (= isospory, Fern); then $(\beta)$ differentiated, Heterospory (Selaginella), in two sizes, micro- and mega-; the megaspore becomes reduced to I only $(\gamma)$, in turn non-discharged, and hence requiring to be $(\delta)$ 'pollinated' in situ.

The mechanism thus runs closely parallel, but has nothing to do with 'male' and 'female'; sexuality being solely a phenomenon involving a nuclear fusion. Hence flowers, or a plant, bearing microspores, may be termed 'staminate', but not 'male', except in a wholly metaphorical or loosely conventional sense, inherited from the time when stamens were thought to be male organs (Linnaeus). Pollination is not fertilization, though it necessarily precedes the latter. The megaspore enclosed in its megasporangium ultimately initiates the sud-statse (Gymnosperms), and external water ceases to be required for fertilization as the 'plant' attains the full land-habit. 
PINUS SYLVESTRIS, the most characteristic soft-wooded Conifer of the $\mathrm{N}$. Temp. region, also the most highly specialized type of Gymnospermous tree of $\mathrm{N}$. Europe; indigenous to Great Britain, but only left wild in Scotland, hence Scots Pine or Scotch Fir.

I. Spring Shoot. Succulent young shoots 2-3 in. long, cut in May, show the new season's growth in active condition; the young bifoliar spurs in axils of brown bud-scales, enclosed in silvery membranous scales of the spur-axis, and arranged in spiral construction ( $5: 8)$; growing-point in T-bud, with investment of scales; laterals just behind it, to give the 'false whorl' of the season.

In transv. sect. about an inch behind the apex, note:-

(r) Irregular shape of section, 5-8-lobed owing to pressure of spurs.

(2) Very regular circle of ill-defined V.B. $(13-15)$.

(3) Cortical region of parenchyma (to $50 \mu$ diam.) with starch-storage.

(4) Central pith of similar parenchyma $(30-50 \mu)$, loosely lacunar.

(5) Epidermis sclerosed and thickened, stone-cells beneath it at the angles.

(6) Conspicuous series of resin-ducts in cortex ( $150-200 \mu$ diam.), with lining layer of secretory epithelium, as small units $\left(1_{5}-20 \mu\right)$ with granular contents.

The Vascular Bundles are differentiated into protoxylem of small spiral tracheides internally; the beginnings of pitted tracheides of the metaxylem and the first xylem resin-duct may be traced. On the exterior of the V.B. tract parenchymatous protophloem, and radial rows of ill-defined sieve-tubes (IO-I $5 \mu$ diam.) with thick cellulose lining layer. Between $\chi$ and $\phi$ a broad zone of undifferentiated meristem as the cambium, in radial rows, I $2-15 \mu$ wide, and I $2-I_{5}$ cells deep, expressing the activity of bundle growth. Med. rays, of parenchyma elongated radially, are freely produced at intervals of I-5 radial rows.

Note, there is no differentiation of endodermis, pericycle, or scl. fibres: leads of vascular strands passing off to spurs are cut obliquely. thickening.

In longit. sect., xylem of spiral tracheides only, I $5 \mu$ diam., with close spiral

In longit. sect. of apex, the dome-shaped growing-point appears as a low curve, $.5 \mathrm{~mm}$. across, of very uniformly dividing i $5 \mu$ units. The whole apex about 40 cells across, and the rise of young leaf-primordia involving $3-4$ cells.

II. One-year-old Shoots, cut in October, show full season's differentiation of the Vascular Cylinder, as a broad zone of metaxylem surrounded by a narrow zone of Phloem; cortex with ducts, secondary M.R., and periphery of stem with thin layer of cork beneath persistent epidermis. Foliage-leaves and spurs persistent to $3^{\text {rd }}$ year.

In Transv. sect. of stem $5 \mathrm{~mm}$. diam., in further detail, from periphery :-

Epidermis of small cells, sclerosed, with thick cuticularized layer $(6 \mu)$.

Cork, as $2-3$ layers, $50 \mu$ or more, of cells with thin wavy walls, also giving the phloroglucin-react. Phellogenhypodermal $(30-40 \mu$ wide), and I -2 rows of Phelloderm.

Cortex becoming loosely lacunar, some cells dying off, others with chloroplasts: resin-ducts now radially compressed.

Phloem of same characteristic radial rows of sieve-tubes, about $\mathbf{I}_{5} \mu$ wide, with thick cellulose lining, and granular contents ; radially compressed, and crushed out in older portions; phloem-parenchyma of larger oval cells, tangentially elongated; persistent and turgid among crushed sieve-tubes; ray-parenchyma of similar cells radially elongated.

Cambium of 2-3 layers of meristem (resting-stage); with sharp boundary (by phloroglucin-reaction) against metaxylem tracheides.

Metaxylem mainly of pitted tracheides, in very exact radial rows, $\mathbf{I} 5^{-20} \mu$ wide, and about $15 \mu$ radially; as many as 75 in radial series to $\chi^{\prime}$. Bordered pits on radial walls only; ray-parenchyma in radial series, one cell wide, non-lignified, with starch-content, or in winter months large quantities of fat and no starch.

Parenchymatous islands, with resin-duct, scattered irregularly as tracts $100 \mu$ wide, of about $20-30$ cells, and epithelium of few units $(4-8)$, with crushed and dead adjacent cells: M.R. cells also contain terpenes when fresh.

Protoxylem of crushed tracheides, and parenchyma, all giving phloroglucinreaction when dead.

Medulla cells also dying and giving phloroglucin-reaction; largest units extend to $\mathbf{I} 00 \mu$ diam. 
Note, false ring-effects, partial, only due to climatic factors, or to adjustment of growth-curvatures in axis. Strong leading shoots may be $12 \mathrm{~mm}$. diam, at end of first year, and show tracheides $20 \mu$ radially, and 100 in a radial row. In stronggrowing trees the annual rings may be $8 \mathrm{~mm}$. broad.

Longit. Radial Sect. shows more particularly the pitted tracheides of the xylem, and the sieve-tubes of the phloem : also giving clearer view of rectangular cork-cells; phloem of elongated sieve-tubes crossed by ray-parenchyma; metaxylem of pitted tracheides crossed by med. rays; pith of elongated cells with distinct simple pits. Fresh material differentiates well in Chlor. $\mathrm{Zn}$. Iod., and in Phloroglucin-2 $5 \% \mathrm{H}_{2} \mathrm{SO}_{4}$; Note especially:-

(I) Sieve-tubes greatly elongated, with pointed ends (both ends not seen), $10 \mu$ wide, with non-cellulose areas as oval spots $(6 \mu)$ on radial wall facing, as sieve-areas (cf. white spots on deep-blue wall in Chor. Zn. Iod.).

(2) Pitted tracheides, about $1_{5} \mu$ wide, with pointed or irregularly wavy rounded ends (both ends not seen); bordered pits as exact concentric circles (outer I $2 \mu$ diam.), in scattered single series, on radial wall facing only. Characteristic details of Medullary Rays preferably seen in older material.

III. In older well-grown stems, an inch in diam., note in transv. sect. :-

Annual Rings, in metaxylem, from $\mathbf{I}-2 \mathrm{~mm}$. wide, presenting marked differentiation from spring-wood tracheides, $20-30 \mu$ in radial direction; grading to summer wood with radial width reduced to $10-6 \mu$, and thick lining wall $3 \mu$. The contrast between the smallest last-formed summer tracheide, and the large spring tracheide, gives the precision of the ring-effect; but the appearance to the naked eye is due to the dense mass of the summer wood (often up to half the width of the ring). Single radial rows of tracheides may be traced across the growth of several years.

Ring-effects are also shown in the phloem to a lesser extent: a vague line of larger phloem-parenchyma being formed at the end of each season; many such rows may be in sight before being wholly crushed out. These parenchymatous units are long persistent, and store starch; others tannin and calc. oxalate crystals as excreta. The former divide to a certain extent to keep up with the growth of the stem, and ultimately appear in the bark.

In Rad. Longit. Sect. note characteristic details in Medullary Rays :-

(I) Medullary Ray Parenchyma (M.R.P.), of living cells, with cellulose walls, $\mathbf{I} 5^{-20} \mu$, and large nuclei ; radially extended from $5 \circ \mu$, summer, to $\mathbf{I} 80 \mu$ in spring wood; the nuclei being oval and radially elongated also $(3 \circ \mu)$; hence crossing 3-7 tracheides, with which they communicate by one large rounded pit each, or broadly oval in spring-wood, and a diagonal flare in summer wood. The cells store starch in autumn, but show none in summer (Aug), and again only fat in mid-winter.

(2) Medullary Ray Tracheides (M.R.T.), as units similarly elongated, but definitely sclerosed, without contents; the internal wall toothed and jagged, projecting into the lumen; and communicating with the pitted tracheides, and with each other, by small bordered pits $(x \circ \mu)$ : varying in length from $30-15 \circ \mu$, and crossing $\mathbf{I}-6$ tracheides. Usually found in definite radial rows (no mixing) of $1-2$ deep, along the upper and lower margins of the M. Rays. The outer layer is more or less irregularly extended, with sliding effects, vertically between the divergent tracheides, as in the chinks opened up by the pressure of the living and turgid MI.R.P.

(3) In the Phloem the rays continue as living parenchyma, with conspicuous contents and nuclei; but the peripheral series again tend to vertical extension, with characteristic effect in units of no great radial width. In winter the latter store proteid, but starch is also present at autumn starch-maximum. These are distinguished as albumen-cells, and are apparently utilized as 'companion-cells' for the adjacent sieve-tubes with which they communicate by lateral sieve-areas.

In Tangential Section, cut across spring-wood, note the distribution and vertical range of MI.R., also tangential face-view of the tracheide-walls. Rays mostly uniseriate, $\mathrm{I}-15$ cells deep; larger ray's ('fusiform') include parenchyma and small resin-duct. Cf. distribution of M.R.T. in the ray-margins; bordered pits as seen in section; special large pits of M.R.P.; and pointed ends of pitted-tracheides $(\mathbf{I}-2 \mathrm{~mm}$.). In similar section through Phloem note large cells of M.R.P. and tanninsacs with Calc. Oxalate crystals. 
PINUS SYLVESTRIS, characteristic 'Hard Pine' of N. Europe, imported since fifteenth cent. from Baltic ports, as 'Yellow' and 'Red Deal' ('White Deal' $=$ Spruce). Variable in texture according to mode of growth. Finest trunks floated down Vistula to Dantzic; poorer quality from Sweden and Norway, used for building-construction, as in planks. Dry material gives details of dead xylemtracheides and rays: parenchyma poorly expressed: softened by soaking in water, and coloured by phloroglucin-reaction.

I. Naked-eye characters: note width of annual rings, $\mathrm{I}-3 \mathrm{~mm}$. (max. $7-8$ ), marked by dark zone of summer wood $\left(\frac{1}{2} \mathrm{~mm}\right.$.): lighter specks as resin-duct islands, scattered irregularly; M. Rays as fine lines, the broader rays alone visible to the eye.

II. Transv. Sect. : All tissues tend to increase in dimensions in older trees, up to a maximum of about $30-40 \mathrm{ft}$. high, as compared with small growths and buds of branches. An annual ring of $3 \mathrm{~mm}$. shows radial series of 50-80 pitted tracheides, and the spring-tracheides may be $50-60 \mu$ in radial depth. Medullary rays $6-8$ per $\mathrm{mm}$., and $2-\mathrm{r} 8$ rows apart (average $5^{-6}$ ). Demarcation of annual ring very clear; the thickening of the summer tracheides up to $6 \mu$ wide, on a very definite intermediate primary wall.

III. Longit. Rad. Sect. : Note great size of pitted tracheides, up to over $4 \mathrm{~mm}$. long, and $30-60 \mu$ wide, with bordered pits $20 \mu$ or more in diam. (inner circle $6 \mu$ ) often closely set; exceptionally 2 -ranked in spring wood: spiral striation of wall-lining, and oblique pits of summer wood flared along the spiral path.

M.R.P. as before, broadly oval pits, I per tracheide, extending to $4 \circ \mu$ wide radially; occasionally 2 per tracheide.

M.R.T. may be $3^{-4}$ deep in one ray; jagging very steep, and irregularly toothed; bordered pits го $\mu$ diam., also in transverse and oblique end-ivalls.

IV. Longit. Tangent. Sect. : In the largest tracheides of the spring wood bordered pits should be cut well enough to show the torus. Note distinction of uniseriate and fusiform rays, the former rarely more than ${ }_{5} 5$ cells deep $(300 \mu)$. M.R.P. and M.R.T. distinguished by contents and wall-structure.

Alburnum and Duramen: The newly formed tissues are used for conduction of the transpiration current; older tracheides become full of air-bubbles: but so long as the parenchymatous units are alive, the xylem is so far 'sap-wood', and water may be stored in it, or the parenchyma used for storage of reserves as starch. As the living cells die off their contents are lost; excretions only remain, and these undergo chemical decomposition, infiltrating the walls, as tannins, resins, \&c., differentiating Duramen or 'Heart-wood' in colour, texture, and general properties. The alburnum of Pinus is pale yellow, and the duramen pale reddish, hence commercial names. The boundary of the duramen is not exact to the ring-pattern: the differentiation is but slight, and gives no special reaction with reagents.

Knots: As the upper growth of the tree shades the lower laterals, these die; not being definitely cut off by an absciss-layer they remain to decay in situ, leaving dead snags of smaller or larger size. In the course of time the bases are imbedded in the advancing rings, and buried in the wood. In Pinus such laterals, in advanced condition of chemical decomposition, beyond the duramen-condition, broken off short, and covered by healing layers of new wood, are seen projecting obliquely and radially through the timber. Sections of these constitute 'knots'; two forms may be distinguished: e.g., in Pinus, a branch may die at 40 years old, as seen by checking approximate number of rings in transverse section of the lknot, leaving a broken snag on the trunk. The wood of the basal part of the branch is continuous with that of 40 year's growth of timber, being close-grained with reduced growth-activity, and duramen in texture. At the base of the snag, cambium may still continue to follow on for many years (10-20), and the timber gradually encloses the base of the lateral, conformably as before.

The exposed dead wood of the snag undergoes extreme chemical decompostion, becoming resinous and infiltrated to a translucent mass, in which even the walls may become more or less dissolved. This part, as it is gradually imbedded in successive annual rings, is non-conformable with the advancing timber and fills a cavity the interspace being sealed with resin. Sections in a plank give 'loose knots'. 
Note that all laterals go down to the first year's wood; the pith of the lateral being continuous with that of the main axis, and laterals diverge at very approximately the Fibonacci angle of $137 \frac{1}{2}^{\circ}$.

Owing to the laterals being formed in 'false ' whorls each season, the knots are spaced apart at a distance equal to the annual growth of the axis, or commonly I 8 in. to $2 \mathrm{ft}$. (in Pitch Pine as much as $3 \mathrm{ft}$. 6 in.).

Bark: The primary phellogen gives a thin layer of cork cells in radial rows, and up to $50 \mu$ wide, over a period of 7-9 years. The cork tissue differentiated as (I) thin-walled units with wavy walls readily crushed or peeling, and (2) stone-cork layers, I-2 deep, of units with thick sclerosed and pitted walls. This distinction of hard- and thin-walled zones gives a peeling papery bark, separating readily at the phellogen, and requiring no lenticels.

At an age of 8-10 years formation of scale-bark commences, by secondary phellogens cutting deeply into the parenchymatous residues of secondary phloem. On older trees a massive scale-bark is produced, the scales $I-2$ in. wide, and several long, as layers of red tissue, weathering brown externally. The scale-layers are I-2 mm. thick, apparently indicating annual periods. The new phellogens give but few units, about a dozen in the radial rows, differentiating as brown thinwalled zones with more colourless thin-walled tissue $(5 \circ \mu$ wide), and readily separating. Stone-cells are feebly developed. The whole mass consists mainly of loose dead parenchyma, with no contents and little cellulose reaction, but a certain amount of lignification. No lenticels are formed, the cracking of the scales apparently affords sufficient aeration.

Comparison of other species of Pinus: taking $P$. sylvestris as type of 2-needled Pine :-

(I) P. Laricio (incl. var. austriaca) of S. Europe, with somewhat larger tissues: annual rings of strong growth to $10 \mathrm{~mm}$. wide; pitted tracheides more rounded in transv. sect. In Rad. longit. sect., spring-tracheides $60 \mu$ in radial depth; bordered pits to $25 \mu$; pitted tracheides with sinuous ends, across $3-4$ radial rows. M.R.P. with broadly oval pit, I per tracheide; but also commonly 2 in radial direction: M.R.T. with jagged ingrowths short and blunt. The scale-leaf bases of the main axis persist, and enlarge with the growth of the stem; the phyllotaxis pattern of scales in contact-parastichies remaining obvious for 6 -10 years, much in the manner of the cortex of Lepidodendron; the rhomboidal areas increasing to $20 \mathrm{~mm}$. by $\mathrm{I}_{5}$. As the first thin cork with stone-cell bands follows the pattern, the peeling cork of these areas may give an erroneous impression of scale-bark from the beginning. True scale-bark is only formed later. The persistence of the phyllotaxis pattern is characteristic.

(2) P. excelsa, 5-needled Pine; stem with smooth bark for long periods; the first new phellogen cuts deeply into the secondary phloem, delimiting dead tissue, including phloem-parenchyma with calc. oxalate crystals, by thin-walled cork, at 20 years old or more; leaving a distinct zone of phloem with layers of crushed sieve-tubes. Naked-eye characters of wood as in $P$. sylvestris. Rad. Longit. sect. shows :-

M.R.P. communicating with pitted tracheides by one large rounded pit per tracheide, rarely 2 .

M.R.T. with slightly wavy wall, but no internal jagging; minor ingrowths only in the case of large rays: bordered pits $\mathrm{I} 2 \mu$.

(3) Pinus palustris (Pitch Pine), 3-needled form, with marked contrast between deep brown summer wood and yellow spring wood; annual growth considerable in length, but rings narrow, commonly $\mathrm{I}-0.5 \mathrm{~mm}$., pitted tracheides with commonly 2-ranked pits in spring wood.

MI.R.P. typically $2-5$ pits per tracheide, in series two deep (range $\mathbf{r}-8$ ).

M.R.T. with jagging so pronounced that the ingrowths meet across the cavity of the cell to a close reticulum : bordered pits small.

(4) P. insignis (radiala), 3-needled form. Annual rings broad, to $5 \mathrm{~mm}$.

M.R.P. well defined, crossing as many as 8 tracheides, with $2-5$ flared or oval pits per tracheide (rarely I).

M.R.T. distinctly jagged, with acute teeth; and mixed with M.R.P. in same ray, as many as 4 bands in deeper rays. 
The Foliage Leaf (Pinus sylvestris as type); a remarkable construction with extreme xerophytic specialization as the characteristic Pine-'Needle'; a slender, rigid leaf-lamina, about $2 \mathrm{in}$. long, and $\mathbf{I}^{\circ} 6 \mathrm{~mm}$. broad (reducing to $\mathbf{I}$ in. long, and less than I mm. wide on starved laterals), with approximately semicircular section, since 2 closely adpressed units fill a cylindrical bud within a sheathing investment of membranous scales of the bifoliar spur: Normally persisting for 2-3 years.

Note that two units, face to face over the spur-axis, represent a minimum condition of spur-organization for D.V. leaves (the exceptional case of one leaf gives an asymmetrical construction) and older types extend to $3-5$ needles on the spur, as a contact-cycle of spirally arranged leaf-members. The lamina may be regarded as based on a pointed scale-member, in which active intercalary growth gives a longitudinal extension which may be practically indefinite, without corresponding lateral extension; i.e. the more this growth-phase has been exaggerated the longer the 'needle'. The edge is minutely serrate, with small teeth formed from exaggerated 'angle-cells', spaced $\cdot 2-\cdot 3 \mathrm{~mm}$. apart; the lamina often shows a slight spiral twist, and the stomata are arranged in conspicuous stomatal lines (marked by wax), usually IO-II on the upper face, and $12-I_{3}$ on the convex lower face: stomata are formed in these rows at IO-I 2 per mm., and a total estimate for a 2 -inch needle gives I $2-14,000$. The general structure is most readily followed in transverse section of the middle portion of the needle: Reagents, Iodine-sol.; Phloroglucin$\mathrm{H}_{2} \mathrm{SO}_{4}$ : Eau de Javelle.

I. Epidermis, a uniform peripheral layer of cells, isodiametric $(20 \mu)$, with cuticularized layers and cuticle on outer face, cavities reduced to small dot-lumina, walls ultimately more or less sclerosed, the thickening showing 4 diagonal slit-pits at angles. Stomata for each stomatal line, with conspicuous guard-cells, owing to broad sclerosed zone in each, and starch-content, sunk $3 \circ \mu$ below surface; outer chamber flask-shaped with narrow external aperture ( 1о $\mu$ ); subsidiary-cells with thick outer wall build the outer chamber. Exaggerated growths of epidermal cells of angles give the serration of the edges. Hair-developments wholly wanting.

II. Mesophyll, much differentiated and including resin-ducts.

(a) Hypoderm, of sclerosed fibrous cells, I layer, interrupted at the stomata, 2-3 layered at angles of leaf; much less thickened than epidermal cells, but more lignified; small slit-pits only.

$(\beta)$ Plicate Mesophyll of $3(4)$ layers of large cells $(50-90 \mu)$, fairly isodiametric, with pocket-evanginations $\left(3^{-6}\right)$, as the expression of the transverse growth of cells to fill all intercellular spaces: Nucleated, with closely packed lining-layer of chloroplasts $(3 \mu)$ and included starch. The double nature of the peg-like folds $\left(1_{5} \mu\right)$ is seen on clearing with Eau de Javelle. The plications along the surface are in the manner of a palisade-series.

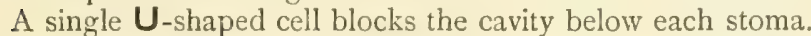

(y) Resin-ducts, peripherally placed, in contact with hypoderm; typically one at each angle, I (2) on the flat side, and 3 (4) on curved side ; total 6-9: ducts about $75 \mu$ diam., with delicate secretory epithelium (I layer), and peripheral zone of thick-walled fibres $(30-50 \mu)$ with slit-pits, small lumen; the thickening shows little lignification even in the oldest leaves.

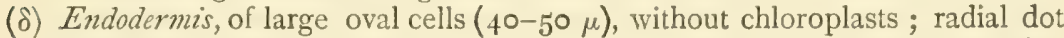
replaced by extensive radial lignification: contents may include a few starch-grains.

III. 'Stele' (a convenient term, following the usage of other stem-terminology, for tissues within an endodermis ; as also 'pericycle', V.B. with 'med.-rays').

(a) Pericyclic region of :-

(I) Parenchematous cells, oval, 50-60 $\mu$, turgid, with protoplasmic contents and starch, arranged perpendicularly to endodermis, and $\mathbf{I}-2$ deep, alternating often very regularly with-

(2) Transfusion-tracheides, with thin walls, deformed by pressure of preceding, with numerous bordered-pits $(5-6 \mu)$ on all sides ; in series of $2-3$; more or less radiating from flanks of xylem, but evenly distributed around the whole contour of the stele. 
(3) Albumen-cells, a group of 6-I 2 small cells $(15-20 \mu$ ) with densely granular contents and large nuclei, on the outer flanks of the phloem of each bundle.

( $\beta$ ) Vascular Bundles, 2, obliquely orientated, with xylem towards upper flat surface, of -

(I) Xylem of spiral tracheides (protoxylem), few, followed by pitted tracheides $\left(I_{0}-15 \mu\right)$ in radial rows $(4-5$ deep); interrupted by radial rows of xylem (ray) parenchyma, at intervals of $\mathbf{I}-5$ tracheids.

(2) Phloem of similar radial rows of sieve-tubes (6-8), interrupted by continuation of ray-parenchyma (often with starch-grains).

(3) Delimiting these, I-2 rows of cells may be classed as 'cambium', as the bundles show slight increase in the 2 nd and 3 rd years; the radial rows of xylem increasing to $6-8$, and those of phloem to $12-20$.

( $\gamma$ ) Between the bundles, and especially over the phloem regions, a band (more or less $x$-shaped) of 'Central fibres' $(3 \circ \mu)$ with thick walls and tannin contents, wall ro-15 $\mu$ thick, with slit-pits more or less sclerosed, particularly characteristic of $P$. sylvestris; some very large $(5 \circ \mu)$.

In longitudinal section note much pitted and elongated walls of epidermis, guard-cells $(60 \mu)$; mesophyll without plication, in palisade $2-3$ layers deep; free intercellular spaces; endodermal cells $\mathbf{1} 50-200 \mu$ long, much pitted. Transfusiontracheides $50-{ }_{5} 50 \mu$ long.

In tangential section of surface, note stomatal lines, conspicuous guard-cells, lignified, $60 \mu$ by 45 over all; elongated slit $3 \circ \mu$ by 6 ; aperture of outer chamber.

Range of Type ; finest needles on main leaders may run 4 in. long and $2 \mathrm{~mm}$. broad, with over 20 stomatal lines (26), and 16 ducts less peripheral. The stele may show I-2 small accessory central V.B., these have no albumen-cells.

Starved leaves of lower laterals, with annual shoot reduced to $\mathbf{I}_{3}-8-3$ bifoliar spurs, with staminate flowers and growth of $\mathbf{I}$ inch or less, may be $20 \mathrm{~mm}$. long, less than $\mathrm{I} \mathrm{mm}$. wide, with 4 stomatal lines on upper surface, and 4 ducts.

Xorophytic Factors. The clue to all peculiarities is to be traced in extensive xerophytic adaptations, as the response to (I) violent winds, (2) intense insolation, (3) extremes of temperature. As opposed to general conception of a mesophytic leaflamina, horizontally extended to give maximum surface for maximum illumination, note:-(I) elimination of bilateral lamina, (2) elimination of orientating petiole, (3) elimination of horizontal position, (4) elimination of outward dorsiventrality. The structure is restricted to an intercalary basal growth in a scale-leaf, of petiolar nature, including the first bifurcation of the single-trace bundle (cf. Ginkgo-petiole); and irregularities affecting 2 primordia together may give a 'double-needle' (cf. Sciadopitys). Intercellular spaces, surface exposed, vascular connexions and tracheides are minimized. As new departures, note, sclerosis of epidermis and hypoderm, screen-function of fibres, sunk stomata, more rigid lignified guard-cells, transfusion tracheides as connected with the xylem (particularly well-developed in Pimus among other Conifers. The size of the leaf becomes a general guide to the amount of photosynthetic work done, and is correlated with the amount of polysaccharide available for cone-building: hence intense insolation or a larger needle implies larger and more massive cones on the annual shoot.

Cotyledons (6-8), about $20 \mathrm{~mm}$. long, and $.6 \mathrm{~mm}$. broad, triangular in section, with very generalized construction; no sclerosed layers, ducts or endodermis; stomata on two radial faces only, plicate mesophyll rudimentary; one central bundle, traces only of transfusion-tracheides.

Juvenile Needles of first year, very similar ; rhomboidal in section, becoming D.V.; with stomata on both sides; one median bundle, 2 ducts; endodermis and transfusion tracheides distinct; mesophyll more definitely plicate.

Winter-buds of bud-scales formed from primary leaves of entire annual shoot (to I00), 5-10 $\mathrm{mm}$. long; conspicuously large in the staminate inflorescence: bases succulent and containing chlorophyll; distal portion of dead tissues with thickened and lignified epidermis; tips and edges reduced to a lamella of one layer of elongated cells, the marginal region frayed out and looking like hairs.

Note. New needles continue growth throughout the season, and may elongate slightly in the second year. Spurs are detached by an absciss-layer. 
PINUS SYLVESTRIS, Scots Pine, Scotch Fir; Forest-tree of N. Europe and Asia, not native in N. America; the only indigenous species of Pinoid, and the type of the group; I00-I $20 \mathrm{ft}$. high, and $3-4 \mathrm{ft}$. diam.; evergreen, pyramidal when young; leader erected, laterals horizontal, with end-shoots ascending at about $45^{\circ}$; ultimately flat-topped by shading of lower branches and cessation of growth in height.

Shoot-system with foliage comprises 5 types of axis and Io of leaf-member, as the expression of considerable specialization in shoot-construction:-(r) Cotyledons, (2) Juvenile leaves, (3) Bud-scales, (4) Scales of main axis, (5) Scales of spur-base, (6) Foliage-needles, (7) Bracts subtending staminate flowers, (8) Scales at base of floral shoots (perianth), (9) Stamens (microsporophylls), (10) Bracts of the ovulate cone. Axes, (I) Erected leader, (2) Laterals, (3) Foliage-spurs, (4) Staminate flowers, (5) Ovulate flowers.

Annual Shoot: Scale-leaves in spiral phyllotaxis, $(5: 8)$ in section of bud-apex T-bud pointed $(7 \mathrm{~mm}$.), with many bud-scales and conoidal apex; season's growth 6-I 8 in. (reduced to $\mathrm{r}-\frac{1}{2}$ in. only in starved laterals). Lateral leaders formed only in axils of few $(1-5)$ scales at the distal end of the shoots, giving 'false whorls' as the expression of annual increments of main axis; none on starved laterals.

spurs in axils of all remaining scales, with basal membranous sheathing leaves and suppressed apex; each bifoliar, with 2 foliage-needles, $2 \frac{1}{2}$ in., to $I$ in. on starved laterals, flat upper surfaces superposed, functional $2-3(5)$ years.

Note extreme xeromorphic specialization of 'needle'-habit, leaf-anatomy, absence of hairs, terpene-exudation as heat-screen, effect of stiff needles in reducing windvelocity, sunken stomata, reduced leaf-area, feeble vascular supply.

Flowers, diclinous (monoecious), spirally constructed, apetalous, anemophilous; available for a week or so at end of May.

I. Staminate Flower: borne in considerable numbers ( 100$)$ in spicate 'inflorescence' aggregation, in axils of scale-leaves at the base of new spring-shoots, and replacing foliage-spurs : prepared in winter-bud, maturing in April, functional before the new foliage is grown (May 25). Basal scales constitute a rudimentary perianth; stamens 60 or so, in spiral series, $2 \mathrm{~mm}$. long; filament negligible, with overlapping connective-crest: pollen-sacs (2) on lower surface, each dehiscing longitudinally by mechanism of banded epidermal cells. Pollen grains are formed in tetrads after meiosis.

The floral axis elongates in expanded flower, $3 \mathrm{~mm}$. to $5^{-10} \mathrm{~mm}$. : Pollen yellow, oval, $55 \mu$ long, with 2 inflated 'wings', $80 \mu$ over all : output enormous, cf. 'sulphur showers'; rough estimate a litre per tree : old flowers withered are soon shed, leaving bare places on annual shoot axis.

II. Ovulate Flowers, as young 'cone'-formations, of obscure morphological value. The term carpel may be avoided, as the relation of the paired ovules to the primary leaf-units is not apparent at first sight. The term flower will be used provisionally as implying an axis comparable with the staminate shoot. This ovulate construction is found replacing leader-shoots $(\mathrm{I}-3)$ only at the distal end of the annual growth. Similarly performed in the winter-bud ( $1 \mathrm{~mm}$. Dec.), emerging with the foliage-needles in May, and erected, $5 \mathrm{~mm}$., surpassing the T-bud.

Constructed of rose-coloured, spirally-arranged, close-set 'bract-scales', grading from basal rudimentary 'perianth'-members to functional 'bracts' with 'cone-scale' growth in axil; the latter associated with 2 'inverted' ovules in the angle on the upper surface, diverging obliquely outwards.

Note. The 'bract-scale' probably expresses a vestigial carpel; the ovules being now relegated to the axillary region; the 'cone-scale' is a secondary growth originally used to seal the primitive cone, now precociously formed and functional at pollination.

Floral Mechanism: intercalary extension of the cone-axis allows separation of the bract-scales by narrow chinks, so that wind-borne pollen falls between them (May 20-25). The ovules $(.5 \mathrm{~mm}$. long) consisting of nucellus, one integument, and micropyle, represent the megasporangia; the megaspore at this stage being a single cell centred at the level of the integument-base. The nucellus secretes a drop of fluid, and pollen-grains drifted down the chinks are withdrawn through the micropyle (drop-mechanism), to anchor on the nucellus-apex by a short germ-tube.

The Green Cone: The pollen-grains are shut in by a growth of the integu- 
ment-lips, the cone-scales are pressed together by subsequent growth, and the whole system is inverted by a curvature of the cone-axis. In this stage, with little further growth $(\mathrm{I} 2 \mathrm{~mm}$.) it perennates over the summer and succeeding winter, on a stalk Io $\mathrm{mm}$. ; the scales sealed by resinous exudation, and exposed scale-facets covered with a cork-layer. These facets with the pointed 'mucro' as the first formed tip of the cone-scale persist as the umbo of the adult cone.

Note. The pollen-grains germinated on the nucellus, with short haustorial germ-tube, perennate over the winter; the megaspore continues to grow as the female prothallus, and is $.25 \mathrm{~mm}$. long in the perennating stage; the two sexual plants in this condition being separated only by a few cells of the nucellar region.

Further development takes place in the spring of the second season. By the end of June ( 13 months after pollination) the green cone is $\mathbf{I}_{2} \mathbf{2}-2$ in. long, conspicuous at the end of the previous season's growth; the cone-scale facets in spiral pattern $(5: 8)$, closely-compacted, with green secondary extension of an apophysis-region retaining the central umbo of the younger stage.

The Female Prothallus: The ovules ( 2 per scale), grown to $4 \mathrm{~mm}$. long, are protected $5 \mathrm{~mm}$. below the surface by the overlap of 3 scales, so far non-sclerosed. The enclosed prothallus is a cellular mass, $3 \mathrm{~mm}$. long, of simple thin-walled units $(50 \mu)$. Such ovules are readily cut in median longitudinal section, showing attachment to the scale-surface along one side, integument, micropyle, nucellus-apex, pollengrains in situ, and prothallus with oospheres $(3-5), 2-3$ being cut in one section, at the micropylar end.

The oospheres are large oval cells, $400 \mu$, with vacuolated cytoplasm, and a large nucleus, 100 $\mu$. Each oosphere with trace of 'neck-cells' and 'ventral canal cell' expresses the relic of an archegonitum, now sunk in the tissue of the prothallus.

Note. The female prothallus is cellular, with remains of definite archegonia, but is wholly enclosed and parasitic on the tissues of the nucellus: i. e. remaining inside the megaspore, and within the megasporangium wall.

Pollen-tubes digest irregular tracks through the nucellus and penetrate the oospheres. Fertilization (siphonogamic) takes place about June 25 .

The Male Prothallus: Germination of the pollen-grains begins before they are matured as spores: two vestigial prothallial cells are cut off, and may persist as traces in the wall of the free grain, the visible nucleus being that of the third cell: this delimits a 'tube-nucleus', 'stalk-nucleus', and a central unit, separated by cell-walls; from the last, two male gamete-nuclei are produced, which pass down the pollen-tube. Only one is used in fertilizing one oosphere. More than one grain may so germinate.

Embryology recapitulates in minimum form the case of a coenocytic embryo, now restricted to the base of the large oospore: more than one oosphere may be similarly fertilized (Polyembryony); and the product of one oospore branches to 4 'head '-regions, these being thrust down into the endosperm-tissue (prothallial) on elongated 'suspensor' units.

A condition generally described as 3 tiers of 4 cells each, gives 4 embryo-head cells on 4 suspensors, attached to 4 rosette-cells. The head-cells segment to multicellular constructions in which a stem-apex, cotyledonary outgrowths, and a radicleend are differentiated, without special reference to the plan of cell-segmentation. Ultimately one 'embryo' grows at the expense of all the others, with distinct radicle, plumule, hypocotyledonary axis, and 3-8 cotyledons, embedded in the endosperm.

Note. The ovules do not increase in size after fertilization; the embryo is parasitic on the cells of the female prothallus; the latter is conveniently indicated as endosperm since it stores food-material in the seed-stage, although not strictly homologous with the endosperm of the Angiosperm.

Seed-stage: Food-supplies accumulate in the endosperm as starch and fat; ultimately all are converted into fat ; the peripheral layers undergo sclerosis as stonecells of the testa (mainly nucellar in origin). The cone-tissues rapidly harden by general sclerosis, immediately after fertilization (hard-cone), and the whole loses water as the tissues die. A slip of tissue delimited from the cone-scale surface remains attached to the seed as it is also abstricted, and constitutes a 'wing'-extension. The adult seed is $4 \mathrm{~mm}$. long, with pointed micropylar end. A flat asymmetrical, unilateral wing-lamina, $10 \mathrm{~mm}$. long and broadest about half way up, subserves wind-dispersal; but the seeds possess little vitality when air-dried. 
PINUS (66-80), widely distributed in N. Hemisphere; characteristic trees of N. Temp. forest zone, with outlying strays in N. Africa, Canary Is., Burma, Philippines, and Malay; only I sp. (P. Merkusii ) crosses the equator. Finest types on the Pacific Slope. Special centres of distribution: Western States of N. Amer. (2 I sp.), Eastern States (1 5), Mexican highlands (1 2), Mediterranean Region (5), Asiatic (I 4), in foothills of Himalaya, to Japan.

European forms deteriorate northwards ( $P$. sylvestris), and on mountains (P. montana); American forms deteriorate in N.W. (P. Banksiana, Jack Pine), $P$. contorta from roo ft. to a bush in Sphagnum bogs (Alaska), and coning at a few inches (Californian wastes). Bush-forms also in Japan. The finest tree is P. Lambertiana (Sugar Pine), $250 \mathrm{ft}$. or more recorded, with $100 \mathrm{ft}$. clear shaft, 6-1 $2 \mathrm{ft}$. diam. (Oregon and California).

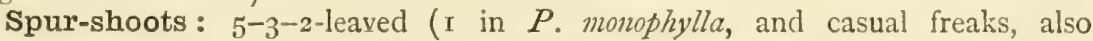
exceptionally 4-8). False whorls at end of annual shoot typical, an older phase as additional 'whorls', also cones (2-5 per annum), so called 'multinodal' effect in some sp. ( $P$. radiata at Monterey, old Pitch-Pine, $P$. muricata, $P$. Banksiana, $P$. Coulteri). Adventitious shoots from old trunks, with needles or juvenile leaves $(P$. rigida), in cracks of bark, and spurs may continue growth. Freely regenerating from old stumps ( $P$.rigida after forest fires), and from coppice-shoots ( $P$. canariensis).

Foliage-needles range to a foot long ( $P$. palustris), $\mathrm{I} 6-\mathbf{I} 8$ in. ( $P$. longifolia). Basal sheath of spur as much as an inch long; persistent $(P$. Pinea), or deciduous $\langle P$. excelsa). Scales of the main axis decurrent, conspicuously so in $P$. Laricio, or not, leaving a smooth stem $(P$. excelsa).

Staminate flower, $\mathrm{I}$ inch to $2-3$ in. ( $P$. palustris); dense inflorescence (P. Pinaster). Pollen has been known to be drifted 400 miles.

Ovulate flower, more distinctly stalked $(P$. excelsa); solitary in depauperated $P$. sylvestris, $P$. montana; in false whorls, clusters $2-5$ ( $P$. excelsa), $5^{-20}(P$. Pinaster, max. over 60): $\frac{3}{4}$ in. to $\mathbf{I}$ in. long; cone-scales often more acuminate (pollencollecting brush). Younger cones erect over winter, sessile ( $P$. austriaca), on stalks I-2 in. $(P$. Strobus $)$. Inverted cones on short stalks become markedly eccentric; scales on outer exposed side presenting exaggerated apophysial developments.

Adult cone: longest $P$. Lambertiana, $2 \mathrm{I}$ in., heaviest $P$. Coulteri, $2-3 \mathrm{lb}$., and a foot long; small in $P$. montana ( $1 \frac{1}{4}$ in.): 2 -season period typical, but 3 years' growth in $P$. Pinea. Cones typically dropped after seed-shedding ( $P$. Laricio), do not open $(P$. Cembra $)$; persist indefinitely, open, ro years $(P$. radiata $)$, closed, 30 years ( $P$. muricata); opening after forest fires ( $P$. Banksiana), buried by bark and even submerged unopened $(P$. clausa $)$. Such features express failure of original opening and abscission mechanism. Axis breaks away above basal scales ( $P$. palustris); basal scales reflex and shed $(P . P$ inea $)$, suggesting older mechanism of cone-scale shedding.

Seed up to $\mathbf{I}$ inch, with massive stony testa $(P$. Pinea); large seeds taken by birds (Crossbill), squirrels, dormice ( $P$. Cembra); edible ( $P$. edulis, $P$. monophylla, N. Amer., P. Gerardiana, Himalya); cultivated for food (P. Pinea, Medit. and S. Africa).

Dispersal: Normally the cone-scales diverge by hygroscopic tensions on desiccation, and the apophyses may strongly reflex $(P$. Coulter $i) ; P$. clausa commonly fails to open, and $P$. Cembra has lost the mechanism. The seed-' wing', up to $\mathrm{I} \frac{3}{4}$ in. long, may be firmly attached $(P$. excelsa), or readily separates $(P$. Pinaster $)$ from the seed; being asymmetrical, it produces a spinning rotation in the falling seeds, which thus attain a limiting velocity of $2 \frac{1}{2}-3 \mathrm{ft}$. per sec. after falling a few feet. In the case of massive edible seeds the wing reduces to a functionless rudiment $(P . P$ inea $)$, and is left on the scale, or represented by a ridge only $(P$. Cembra $)$. Hence large seeds with considerable food-storage are clearly secondary: the case of the small seed with wing, wind-dispersed from an opening cone, as in more generalized Abietineae, is undoubtedly the original condition, as the abscission of useless parts, as dead cones and scales, is also primitive.

Germination follows the normal course for oil-storage, and epigeal cotyledons, with extrusion of the radicle at the micropylar end, elongation of the hypocotyl, and withdrawal of the numerous linear cotyledons (to $1_{3-15}, P$. Pinea); the latter 
commonly elevate the testa; the hypocotyl erects geotropically, and the cotyledons diverge in a whorl. Growth of the plumule with juvenile leaves follows in the first season, spur-growths normally in the second season, and lateral leaders in the third year ( $P$. sylvestris), A larger embryo in $P$. Pinea; the deep-sinking root is characteristic, cf. $P$. palustris with deep root, and plumule remaining short for 5-6 years. Annual increment of young plants commonly $\mathrm{I}-\mathrm{I} \frac{1}{2} \mathrm{ft}$. per season, with subsequent slight extension. Flowering at $\mathrm{r}_{5}-30$ years old ( $P$. sylvestris).

Classification follows conventional lines, combining several factors of unknown value, as by $5^{-3-2-n e e d l e d ~ s p u r s, ~ s i z e, ~ f o r m, ~ a n d ~ d e t a i l s ~ o f ~ c o n e, ~ u m b o ~ t e r m i n a l ~ o r ~}$ central, apophysis rhomboidal, crested, ridged, spinous, or hooked. For empirical schemes cf. Engelmann (1880), Koehne (1893), Shaw (1914). For cones of available forms :-

\section{Five-needled Pines.}

P. excelsa (Blue Himalayan Pine), $80-\mathrm{r} 20 \mathrm{ft} ., 3 \mathrm{ft}$. $6 \mathrm{in}$. diam., leaves $5^{-8} \mathrm{in}$., cone curved, cylindrical, $6-10$ in., in clusters of $2-5$, stalk $I-2$ in.; scales soft, $(3: 5)$ seriate, apophysis rhomboidal, striate : umbo terminal, pointed, $2 \mathrm{~mm}$.

P. Lambertiana (Sugar Pine); sugar (Pinite) exuded from old heart-wood; I 50-200 ft. or more; 6-I $2 \mathrm{ft}$. diam., Oregon and California; needles $3-4$ in.: cones I $2-2 \mathbf{I}$ in. by $3-4$ : scales thin; apophysis-margin slightly reflexed in open cone, umbo rounded: Seed I $5 \mathrm{~mm}$., wing $20 \mathrm{~mm}$., cots. I 2-I 5 .

P. Strobus (Weymouth Pine, American White-Pine, Eastern States), I 50-I 75 ft., $5 \mathrm{ft}$. diam., needles $3^{-4}$ in., cones $4^{-6}$ in., very slender, $(3: 5)$ seriate; cone-scales smooth, rounded margin; umbo terminal. $P$. monticola (Western States) closely similar, cones relatively broader.

P. Cembra (Swiss Stone-Pine), 70-1 $30 \mathrm{ft}$., leaves $2 \frac{1}{2} 3 \frac{1}{2}$; cones $2-3$ in. by 2 , ovoid; apophysis striate, umbo terminal ; indehiscent, gnawed by squirrels; seed $\frac{1}{2}$ in., without any wing, sunk in cone-scale tissue.

II. Three-needled Pines.

P. radiata (= insignis), Monterey Pine, California: Ioo ft.; to $6 \mathrm{ft}$. diam., needles $4^{-6} \mathrm{~mm}$., cones $3^{-5}$ in., massive, asymmetrical, large rounded apophyses on exposed side ; umbo central; cone persistent many years, 'multinodal' at Monterey. Seed $6 \mathrm{~mm}$., wing $20 \mathrm{~mm}$.

P. Coulteri, Californian, $70 \mathrm{ft}$; ; to $4 \mathrm{ft}$. diam, needles Io-I 2 in.; massive cones, ro-1 4 in.; scales $(5: 8)$ seriate; apophysis rhomboidal, exaggerated on exposed side to conoidal form with strong hooked umbo ( $10 \mathrm{~mm}$.).

P. longifolia, Himalyan. Needles pendulous, 16 in.: cones $5^{-8}$ in., massive, apophysis a conoidal reflexed hook, umbo apical.

\section{Two-needled Pines.}

P. Pinaster (= maritima), Cluster-Pine, Biscay coast ; 60 $80 \mathrm{ft}$. to 120 , and $4 \mathrm{ft}$. diam., needles $5^{-8}$ in., cones in 'whorls', often excessive : $3^{-6-7}$ in., apophysis rhomboidal, $(5: 8)$ seriate, with strong transverse crest, and pointed umbo, $3-4 \mathrm{~mm}$.

P. Pinea (Stone-Pine, Parasol Pine, Mediterranean Reg.), Ioo ft. to $6 \mathrm{ft}$. diam., needles 5 in., cones $5-6$ in., massive ovoid to sub-spherical; scales smooth, ( $8: 13$ ) seriate, apophysis with three annual growths, umbo smooth: Seed $\frac{3}{4}-\mathbf{I}$ in.

P. Laricio (= migricans), Corsican Pine, I00-1 $50 \mathrm{ft}$., needles $4-6 \mathrm{in}$., cones $2-3$ in. ovoid tapering, scales $(3: 5: 8)$ seriate; apophysis rhomboidal with transverse crest and slight rounded umbo projection and minute reflexed spine.

P. austriaca (var. of preceding). Foliage darker, needles stouter, scales of axis and buds exaggerated: cones larger, brighter coloured, apophysis more decided, at best a rounded knob.

P. sylvestris, cones $1 \frac{1}{2}-2 \mathrm{in}$, lapering, apophysis rhomboidal, smooth or prolonged in curved process on exposed side or base, often strongly hooked; $(5: 8)$ seriate; umbo with reflexed mucro.

P. montana (= Pumilio), 5-I5 ft., cones small, apophysis rhomboidal with alightly bevelled facets; $(5: 8)$ seriate : umbo with minute reflexed point.

P. muricata (Prickly-Cone Pine), California; cones 3 in., ovoid, apophysis conoidal, spinous on exposed side; indefinitely closed: varies to 3 -needled: cones in false whorls below the laterals (multinodal).

P. Banksiana (Jack Pine), cones $2 \frac{1}{2}$ in., very slender, commonly distorted; $(3: 5)$ seriate, apophysis flat (umbo inconspicuous) with radiating striae. 
ABIETINEAE: a series of generic types (9), more or less isolated, but approaching the type of $P$ inus in many features of special organization, as in needlefoliage, timber-construction, mechanism of floral-shoots, and definite 'cones', in which the cone-scales are spirally arranged, each bearing 2 inverted ovules only, and constituting the predominant, externally visible feature of the fruiting structure.

The group includes Pinzs (70), as the largest genus, and distinctly the most highly specialized type of the series; Pinus alone having spur-shoots restricted to $2-5$ needles, and woody cones with conspicuous cone-scale facet (apophysis and umbo). Picea (20), Abies (26), and Larix (14) are the more generalized types; the last distinguished by its assumption of the deciduous habit; these 3 genera are widely distributed over the whole of the N. Temp. forest region of Europe, Asia, and N. Amer.

Other types are more isolated, and represent vestigial forms of intermediate specialization; e.g. Cedrus, localized in mountains of the Old World, approaching Larix in its spur-shoot-system. Pseudolarix, a monotype of Eastern China, is deciduous. Keteleeria is also a Chinese monotype. The remaining genera are restricted to N. America (with extensions to the Asiatic side of the Pacific), Tsuga (7) a more generalized type, and Pseudotsuga, a more elaborate form, combining characters of Picea and Abies.

These associated genera cannot be arranged in any linear scheme, but each may be regarded as presenting a partial retention of a set of factors common to the older race, as variants on a general theme in which some types have passed beyond the others, though stationary or even retrograde in other respects.

I. CEDRUS (3), forest-trees of N. Subtropical forest-belt, Old World: as geographical races, $C$. Deodara (Himalya), C. Libani (Syria), C. atlantica (Atlas Mts.); of organization older and more generalized than Pinus, with special phases of xeromorphic habit; the type is :-

Cedrus Libani (Lebanon, Asia Minor, and Cyprus), attaining 2,000-3,000 years: 90-I $20 \mathrm{ft}$ : diam. max. $34 \mathrm{ft}$. Evergreen; main leader erect, laterals horizontal, pyramidal at first, table-topped later.

Annual shoot; 6-8 inches ( 3 in. on weaker laterals): primary leaves spirally arranged as slender needles, $\mathbf{1} 5-30 \mathrm{~mm}$. Terminal bud with conoidal apex at base of crater, for protection of primordia (cf. longit. sect.). Relics of leaf-scars and winter bud-scales persist for to yrs, on bark. No false whorls of leader laterals. In axils of a few leaves of current year (without rule), but more towards the end of the shoot, spurs are produced in the first season, as spiral clusters of a few $(8-\mathrm{I} 3)$ short needles (10-1 $2 \mathrm{~mm}$.). Primary needles fall in 2 nd and $3^{\text {rd }}$ year. Subsequent foliage from spurs only; in the second season these produce 20-30 needles $(20 \mathrm{~mm}$.), with terminal crateriform bud. Spur-foliage may persist for $2-3$, or even $4^{-6}$ years. Growth of spurs is continuous, with leaf-production over I5 or more seasons, averaging 2 I needles each year.

Dorsiventral shoot-systems. All spurs erect to the upper side of horizontally spreading laterals; so exaggerated on older axes that they appear borne on upper surface only. Dense growths of short spurs give the door-mat effect of the foliagesystem. Spurs may branch occasionally, not more than one lateral as a short spur in one season; and any spur with illumination may grow out as a leader; a large number of intermediate stages assist in the aggregated mat of foliage. Old spurs show a characteristic ' jointed' system of segments $(2-3 \mathrm{~mm}$.), in which scars of the needles ( 2 cycles) alternate with the spiral bud-scales of the old terminal buds. This may continue for $\mathbf{I} 5$ years or more : spurs have no annual rings in the xylem.

Staminate flower large and conspicuous, borne terminating spur-shoots on growth several years $(5-7)$ old: formed in August and functional in September, October; erected, $30 \mathrm{~mm}$. in bud, $3 \mathrm{in}$. when expanded; including $300-400$ stamens, in spiral series: stamens $4 \mathrm{~mm}$. with connective crest bent up at right angles: Pollen 2-winged, $5 \circ \mu$ diam., $80 \mu$ across wings. Shed in November.

Ovulate flowers with similar position, few, inconspicuous, small green-purple cones, $\frac{1}{2}$ inch long, erected; ovules 2 on scale, and inverted. Cone-scale functional in pollen-collection, Oct.; full size in succeeding June at fertilization-stage, as 
massive cones $3^{-4}$ in. long: orules protected $6 \mathrm{~mm}$. below surface by the overlap of $5^{-6}$ scales.

Cones matured in November of and year; erected, ovoid, of $150-200$ scales, with flat or depressed top, $3-4 \frac{1}{2}$ in. by $2 \frac{1}{2}$ : Scale-facets $45 \mathrm{~mm}$. by 5 , tangentially extended, with minute apex, membranous margin, and edges divergent on drying. Normal method not induced by desiccation; but, soaked in autumnal rains, bud-scales separate from the slender central axis, and fall away from above downwards; sterile apex shed in one piece, and seeds dispersed by wind, December: scales up to 2 in. across; seeds $5 \mathrm{~mm}$. long, wing $30 \mathrm{~mm}$. long, 24 broad. Cotyledons 6-9-I I : germination normal, seedling 9 inches in rst season.

C. Deodara, the least xerophytic type, annual shoot a foot or more long; longer needles, $30-40 \mathrm{~mm}$., in looser tufts, ascending $45^{\circ}$; leaders and laterals flexuous or pendulous; secondary laterals drooping, in the manner of Larix. Staminate flower, Sept.-Dec., the largest in the Abietineae; 2 in. in bud, elongating to + in.; stamens 800 , pollen-sacs $5 \mathrm{~mm}$., pollen winged, $90 \mu$ over wings. Cones smooth, $3-5$ in. by $2-3$, with flat top.

C. allantica, spur-shoots longer, more copiously branched; cones shorter, more cylindrical, often with pointed apex. Main laterals long, ascending at $45^{\circ}$.

II. LARIX (I4). Forest-trees of N. Temp., Europe, Asia, N. Amer.: cf. L. europaea, L. sibirica, L. americana, L. Griffithii (Himalya): deciduous, in northern forest, and essentially alpine: less xeromorphic in summer needles. Otherwise with the habit of Cedrus; depauperated in flowers and cones.

Larix europaea (Larch), not indig.; Mts. of Central Europe; Io0-I50 ft., to 3-5 ft. diam., pyramidal, with slender ramuli, pendulous in marked varieties.

Annual shoot, leader $\mathbf{I}-2 \mathrm{ft}$., needles $(3 \circ \mathrm{mm}$.) spirally arranged: T-bud with slight crater-formation: no false whorls; laterals as buds without rule in axils of leaves of previous season, giving spurs in the second year; spurs carry 40 or more foliage-needles each season, for several years, but do not elongate $\left(\frac{1}{2}\right.$ in.). Any spur may grow to a semi-leader; large numbers of these (more or less pendulous) are characteristic.

Staminate flower, 5-10 mm., terminating a spur without foliage, turned to lower side of branch. Pollen spherical (not winged), $80 \mu$ diam.

Ovulate flower, crimson (or white) erected, $\frac{1}{2}$ inch, above young needles of spur : numerous, often $\frac{3}{4}$ inch apart; bracts divergent, $9 \mathrm{~mm}$. long, with pointed apex and reflexed marginal lobes, 50 or more, about 30 fertile; transitional to needles below (and often above in 'proliferating cones'), functional in pollen-collection, and so far distinct from Cedrus: cone-scale minute, $\mathbf{I} \mathrm{mm}$.; growing in green cone later. Pollinated April, fertilized June, matured in one season.

Adult cone, ovoid, erected, $30-40 \mathrm{~mm}$.; cone-scales $(3: 5)$ seriate; bract-scale projecting $2-3 \mathrm{~mm}$., and reflexed; scales thin, $10 \mathrm{~mm}$. broad, with rounded margin: seeds small ( $4 \mathrm{~mm}$.), wing $10 \mathrm{~mm}$.; shed by divergence of scales in autumn and spring: old cones persistent many years. Cotyledons $5-7$ : first year's growth $4^{-6}$ inches: seedlings, juvenile needles ( $\mathrm{I}-4$ yrs.); vigorous growths from plants cut back may retain ' evergreen' habit.

TIMBERS: Pimus-woods are readily distinguished by the presence of resin-ducts (implying also fusiform rays) and large pits (I or more) on the radial walls of MI.R.P. All other Abietineae show small pits on M.R.P., and M.R.T. are generally present with smooth lining wall.

Larix, with very distinct reddish duramen, resin-ducts and fusiform rays: M.R.P. with thickened and uneven transverse walls; end-walls oblique and slightly pitted; small slit-pits ( $\phi$-form) on radial walls, $4^{-6}$ per tracheide: MI.R.T. present with smooth walls. In $L$. Griffithii the tracheides may occasionally present a slight 'spiral thickening' and the MI.R.T a slight 'jagging'.

Cedrus: Duramen reddish: resin-ducts normally wanting (traumatic only), M.R.T. with smooth walls: NI.R.P. with small slit-pits (slits $8 \mu$, and open as 'double contour' pits), 2-4 per tracheide: transverse walls much thickened and pitted, end-walls prominently 'beaded'. C. Deodara, last details conspicuous, and tracheide-pits with ' notched-torus' effect. M. Rays relatively' deep (to $5^{\circ}$ cells). 
III. PICEA (20) Forest-trees of N. Temp., P. excelsa (Europe), P. Morinda Himalya, $P$. álba (N. Amer.).

Picea excelsa (Spruce), not indig., Mts. of Central Europe, I50-200 ft., diam. 3-6 ft.; pyramidal, erect leader and horizontal laterals, no spur-formations; a much more generalized type of Conifer.

Annual shoot with needles $12-20 \mathrm{~mm}$., spirally arranged, pointing forwards $45^{\circ}$, with secondary D.V. position: pectinated on lower laterals, central series loosely forwardly directed; laterally compressed (cf. section). Winter-bud, red, glossy, 3-5 mm., with slight crater-formation; leaves shed in $4^{\text {th }}$ season $(8-12)$, with characteristic pedicel-portion left on axis at leaf-fall. Laterals from buds in axils of needles of previous season, more numerous at distal end of shoot, but without rule: false whorls expressed on main leader, and may be checked by noting bud-scales on laterals for several years.

Staminate flowers, numerous, $\frac{3}{4}$ in., from lateral buds of previous season's shoot, irregularly spaced, more near apex, erected : basal scales as perianth-investment. Stamens numerous, pollen-sacs 2 per stamen, dehiscence longitudinal, pollen winged.

Ovulate flower, large, . 2 in., sessile at end of shoot of previous year, erected, cone-scale, oval, crimson, functional in pollen-collection; bract-scale shorter and not increasing, with long acuminate apex; pollination in May, fertilization in June (six weeks); inverted after pollination to green cone.

Adult cone, pendulous, $4^{-6}$ in., slender, smooth; scales $(5: 8)$, thin, flexible, $\frac{3}{4}$ in. wide, with truncated notched apex. Seeds $4 \mathrm{~mm}$., wing $\mathrm{I} 2 \mathrm{~mm}$., broadest above middle, and end rounded. Matured and shed same season; old cones dropped in spring: cots. 6-10: seedling 2-3 in. high first year. Adult form and branching in $3^{-4}$ th year. Tap-root wanting. Adult continues the ' juvenile' stage.

Note decumbent laterals may root (advt. roots rare in Conifers), such D.V. laterals rarely erect; same applies to grafts from D.V. laterals; at northern limit (Lapland) rooted prostrate shoots give 'Meadow-Spruce', a few inches high only: cf. also fastigiate 'Spitz Firs', and long pendulous shoots of 'Serpent-Spruce'.

Remarkable simulation of cone-growths by attacks of Chermes on T-bud; green and succulent (June), empty and dry (Aug.).

$P$. Morinda with largest cones (6-8 in.), glossy brown rounded scales. $P$. Sitchensis (Sitka Spruce) the finest form, $100-200 \mathrm{ft}$. and $3^{-1} 5 \mathrm{ft}$. diam., cones $2 \frac{1}{2}-4$ in. with narrow scales; seeds $2 \mathrm{~mm}$., wing $7 \mathrm{~mm}$. : reduced to $\mathrm{I}$ ft. high at nearly too years old on exposed cliffs (Vancouver), and a shrub in Alaska.

IV. TSUGA (7) Hemlock, N. Amer.; T. Sieboldii, Japan.

Tsuga canadensis, forest-tree Canada and U.S. to Rocky Mts., 60-roo ft., 2-4 $\mathrm{ft}$. diam., pyramidal, as preceding; needles broader, 8- $12 \mathrm{~mm}$., pectinated in 2 rows, with one median series more or less lying in file along the axis; 2 white stomatal lines to D.V. needle. T-bud half-sunk in crater-apex.

Staminate flower, as in Picea, but small (Io mm.) with few stamens (I 2 ) separated from perianth-scales by a distinct internode. Pollen-sacs 2, dehiscing transversely; pollen winged.

Ovulate flowers, similar in habit, at ends of previous year's shoots, $5 \mathrm{~mm}$., pale green, terminating short laterals and inverting: cone-scale functional in pollencollection (May); cone matured in one season.

Adult cone, small, $\frac{3}{4}$ in. only, of $20-25$ broadly rounded coriaceous scales, gaping when dried, and closing rapidly when wetted; a small 3 -fid bract-scale concealed. Seeds $2 \mathrm{~mm}$., wing $7 \mathrm{~mm}$. : cots. $3-4$; growth very slow, seedlings $3^{-4}$ in. in 4 years.

V. PSEUDOTSUGA (Abietia) I-3, dominant forest-type of Pacific Slope, Oregon, California (and Japan), species or varieties.

Pseudotsuga Douglasii, Douglas Fir : $250-300 \mathrm{ft}$., I0-I $2 \mathrm{ft}$. diam. or more. Leaders may be $2-3 \mathrm{ft}$. Reduced to 18 in. on Mts. of Montana. Foliage and habit of generalized type, needles $20-25 \mathrm{~mm}$., with more or less D.V. displacement and pectination in 2 crests, functional for $3(8)$ years, spirally arranged on erect leaders. 
Laterals scattered; winter-buds long and sharp-pointed $(7 \mathrm{~mm}$.), with no craterformation. Cf. Kew spar, 2 I 4 ft., erected igr9.

Staminate flower, $\frac{3}{4}$ in., orange-red, deflected to lower side of shoots; stamens numerous, pollen-sacs 2 , dehiscence obliquely longitudinal. Pollen spherical, not winged.

Ovulate flower, $\frac{3}{4}$ in., 3 -fid bract-scales red or greenish, as prominent pollencollecting brushes, of slender median lobe with 'stipular' laterals; pollinated second week of May; inverted to green cone, maturing in one season.

Adult cone, pendulous, brown, $2 \frac{1}{2}-4 \frac{1}{2}$ in. ( 6 in. in macrocarpa), with long projecting 3 -fid bract-scale ( $5 \mathrm{~mm}$.): cone-scales soft, broad, and rounded, $(3: 5)$ seriate. Seed $6 \mathrm{~mm}$., wing $10 \mathrm{~mm}$., broad below the middle; dead cones dropped in spring, or persistent. Cots. 5-12. Estimated output of $40-\mathrm{yr}$. tree, $100 \mathrm{ft} ., \mathrm{I}_{5}, 000$ cones, approx. 500,000 seeds, or $5 \mathrm{lb}$. weight.

VI. ABIES (26) Forest-trees of N. Temp. Europe and N. Amer. The most generalized of the group.

Abies pectinata (Silver Fir), not indig., MIts. of S. Furope, I 50-200 ft., $6 \mathrm{ft}$. diam., pyramidal, false whorls more or less apparent on main axes, laterals more horizontal; sub-laterals without special rule as resting buds, short shoots, flowers, \&c.

Annual shoot, needles $25 \mathrm{~mm}$., broad and grooved above, pectinated in 2 rows and crested, upper leaves shorter, spirally arranged on erect leaders ( $\mathrm{I}-2 \mathrm{ft}$.), persisting 8-10 years. Flowering at 30 years, 60 in forest. T-bud markedly crateriform.

Staminate flowers, I in. or more, spaced on previous season's shoots, deflected to lower side; stamens numerous, pollen-sacs 2, dehiscing transversely; pollen winged, output enormous.

Ovulate flowers, slender, 2 in., erected on upper side of shoots ; bract-scales erect and acuminate, pollen-collecting (May): green cones erected permanently with great accuracy on laterals, matured in one season, cylindrical with protruding bract-scale tips.

Adult cone, $6-7$ in. by 2 , slender; scales soft, bract reflexed, cone-scales rounded, detached from slender cone-axis (Oct.). Seeds $7 \mathrm{~mm}$., with broad wing $(8 \mathrm{~mm}$.) closely adherent. Cots. $4-5$.

Seedling, 5 leaves and $2 \mathrm{in}$. high; branching in $3-4$ years; $2 \mathrm{ft}$. at 9 years.

Cf. A. nobilis (N. Amer. $250 \mathrm{ft}$.), a beautiful type; staminate flowers red-purple, elongating to $\mathrm{I}$ in. and pendulous. Cones very large and erected, $6-9 \mathrm{in}$. by 3 in. diam., of over 500 scales, completely clothed by reflexed bract-scales ( $1 \mathrm{~mm}$. broad, with mucro ro $\mathrm{mm}$.). Full size, I $1 \mathrm{~b}$. green, by end of June.

A. Nordmamiana (Caucasus, $200 \mathrm{ft}$.). Laterals horizontal, rigid: cones 6 in. with reflexed bract-scales. A. Veitchii (Japan, 6o ft.), similar habit, cones $4 \mathrm{in.}$, violet-black with anthocyan.

A. Pinsapo (Spain, roo ft.), foliage stiff and prickly, less D.V., ramuli rigid, dense growth; cones 5 in.; bracts shorter than the cone-scales.

\section{TIMBERS :-}

Picea, no marked duramen, hence distinguished as 'White Deal'. Resin-ducts, fusiform rays, and M.R.T. with smooth walls, present: M.R.P. with small slit $(\phi)$ pits, 2-4 per tracheide; transverse walls irregularly waved and pitted; end-walls irregularly pitted (not definitely 'beaded'). Spiral thickening of tracheides and jagging of M.R.T. casual.

Tsuga canadensis: Ducts, resin-cells and M.R.T. present; the ducts (cysts) feeble, and no fusiform rays: M.R.P. with small pits, 2-4 per tracheide; end-walls strongly pitted.

Pseudotsuga: No marked duramen, but conspicuously differentiated rings (summer wood dark-coloured). Resin-ducts, M.R.T., and fusiform rays present; resin cysts in the latter with few $(5-6)$ lining cells. Spiral thickening of tracheides conspicuous, and normally characteristic. MI.R.P. with small slit $(\phi)$ pits, 4-5 per tracheide; transierse and end-walls thick and pitted.

Abies pectinata: Resin-ducts wanting (or traumatic only); M.R.T. typically wanting (or sporadic only): MI.R.P. with small flared pits, $2-6$ per tracheide; the most generalized of the Abietineae; other Conifers closely approximate the same level of specialization. 
TAXODINEAE : An empirical series of vestigial types (8), largely monotypic, left in isolated regions of the Pacific area, distinguished by special characters of the cone-construction, in which a secondary extension below the primary pollen-collecting 'bract-scale' and secondary rudimentary 'cone-scale' takes up both to form the massive scale of the adult cone. The cone-facets thus present a composite aspect (' half and half' cones), each presenting the lower half bract-scale and upper half conescale of the Abietineae.

In other respects the types are interesting as (I) affording a glimpse of an older phase of the Conifer alliance; the shoot-construction is spiral, but the pollen-sacs and ovules are rarely reduced to the minimum of 2 per scale; the latter are normally erected for pollination, and may be inverted later. (2) On the other hand, progression may follow higher phases of shoot and floral organization; the largest trees of the world occur in this series. Sciadopitys (I), Cunninghamia (r), Glyptostrobus (2), Cryptomeria (I), are monotypes- of China and Japan; Arthrotaxis (3), alone in the southern hemisphere, is confined to Tasmania: Sequoia (2) and Taxodium (2) are locally restricted in N. America. Fossil relics occur in the Cretaceous.

I. Sequoia gigantea (Wellingtonia, Big Tree), $275^{-320} \mathrm{ft}$, and $20-35 \mathrm{ft}$. diam., to over 4,000 yrs. old; few surviving; pyramidal when young, to $100-\mathrm{I} 50 \mathrm{ft}$. bare of branches; adult in 500-600 yrs. Laterals drooping and ends erecting, no dorsiventrality; leaves $\frac{1}{2}$ in., acicular, ascending. No bud-scales, annual increments vague; leaves functional for 3 yrs., and relics on bark for ıo. Leader laterals arise without rule (or more numerous at ends of shoots). Wood light and soft, annual rings $\frac{3}{4}$ in., duramen in roth year, red; bark soft, $\mathrm{I}-2 \mathrm{ft}$. thick: few standing over $300 \mathrm{ft}$.; cf. ' Father of the Forest', prostrate, $365 \mathrm{ft}$.

Staminate flower, $4-8 \mathrm{~mm}$., spiral, of few stamens, each 2-4 pollen-sacs : pollen not winged, output enormous, ground coloured yellow.

Ovulate flower, small, fewer, of 40 scales, spiral, acuminate, with long bractscales as pollen-collecting brush, and rudiment of cone-scale; ovules several (ro) per scale, half-inverted. Pollination Feb., enlarged cones ( 2 in.) bright green, matured in second season.

Adult cone, 2-3 in. ovoid, smaller in cultivation, of compact transversely extended scales $(20 \mathrm{~mm}$.) with radiating wrinkled folds; bract-scale with brown membranous edge across transverse diagonal of cone-facet, and slender mucro; $(3: 5)$ seriate. Seeds $5^{-6} \mathrm{~mm}$., with broad lateral wings, $3^{-8}$ per scale, fully inverted from small point of insertion. Cots. $3^{-6}$.

S. sempervirens, Red Wood (Oregon, California), a very distinct form : foliage-leaves as $\frac{3}{4} \mathrm{in}$. needles, dorsiventral, pectinated in 2 series; shoots dimorphic. Characteristic Pacific Slope forest-type, 200-340 ft., and ro-28 ft. diam., full-grown in 500 years. Cones small, $\frac{3}{4}-\mathrm{r}$ in., matured in one season; seeds $3-5$ per scale, with lateral wing-extensions. The roots send up suckers, and old stools coppiceshoots (rare in Conifers); vegetative regeneration usual.

II. Cryptomeria japonica, I 50 ft., $6-7$ diam., pyramidal, Japanese. Foliage and habit much as $S$. gigantea; end-laterals erect, no dorsiventrality; leaves acicular, spirally arranged, ascending, persisting $4-5$ years; no bud-scales.

Staminate flowers clustered in axils of reduced leaves at ends of shoots, $5 \mathrm{~mm}$. long; exposed over winter, functional March; of few stamens each with 5 pollen-sacs ; pollen not winged.

Ovulate flowers terminal on short shoots, $5 \mathrm{~mm}$.; of spirally arranged acuminate bract-scales $(20-30)$, divergent, exposing erect ovules, axillary, with conspicuous integument and first trace of cone-scale growth.

Cone nearly spherical, over I in., with characteristic scale-ends; bract-scale as a pointed reflexed 'mucro', cone-scale portion crested, of $x-5$ tooth-like processes. Seeds 2-6 per scale, erect, angular, $6 \mathrm{~mm}$., narrowly winged; matured in one season.

III. Taxodium distichum, Virginian Swamp-cypress (N. Amer., Eastern States); $100 \mathrm{ft}$. 4-5 diam., pyramidal when young, flat-topped ultimately; deciduous. Winter-buds minute, leaders few; T-bud small, conoidal; abundant spur-system of short shoots, $3^{-4}$ in., with leaves (50 or more), Io mm., spirally arranged and pectinated in 2 rows (much as in Taxus); produced on first year's growth, and 
renewed on older wood for 15 years. Shed en masse November, leaving circular scars, renewed laterally.

Staminate flowers panicled, on ramuli without needles, 3-5 in. branch systems, at ends of laterals : $5 \mathrm{~mm}$., with internodal extension above perianth; stamens ( $\mathrm{I} 5$ ) spirally arranged; pollen-sacs $3^{-6}$.

Ovalate flower solitary, of short bract-scales, with 2 erect ovules per scale; cone an inch or more diam., very solid, ellipsoidal, matured in one season, of mucronate bract-scale portions and crested cone-scale portions: seeds erect, 2 per scale; cots. 6.

Note. Special case of 'respiratory roots' (knees) in swampy ground.

T. mucronata, evergreen, Cypress of Montezuma, the big tree of Tule (Mexico), over $50 \mathrm{ft}$. diam., trunk thickened by descending roots.

IV. Sciadopitys verticillata, Umbrella Pine; Japanese monotype, 90-I50 ft., and $3 \mathrm{ft}$. diam., pyramidal; with bifoliar spurs in double cycles as false whorls of needles (in the manner of starved Pinus sylvestris), but needles large and fused as 'double-needles', 3-4 in.

Staminate flowers clustered at end of shoots; pollen-sacs 2 per stamen.

Ovulate flowers usually solitary, giving cones $2-3$ in. long, scales $2: 3: 5$ seriate, of distinct transverse regions: seeds inverted, about 7 per scale, with lateral wingmargins ; cots. 2.

Theory of Abietineae: Comparison of the few surviving types, beyond the case of the highly specialized Pinzes, shows that the original habit included needle-foliage on the main shoots (retained as 'juvenile-leaves' in Pinus) and the general production of laterals as leaders at any point on the annual shoot (Cedrus, Larix, Picea, Abies, Psendolsuga), a relic of which is regarded in Pinus as the 'multinodal' condition. Radial organization of the branch-system is clearly older than phases of dorsiventrality, the latter being most advanced in species of Abies and Tszuga. Early stages of spurdifferentiation are seen in Cedrus and Larix to be further specialized in Pinus. Larix and Pseudolarix attain to the deciduous habit.

The flowers are simple strobili, terminating laterals, and exhibit a marked tendency to minimum reduction: Cedrus retains the finest micro-strobili, and all show the minimum construction of two pollen-sacs per stamen. Winged pollen is a novelty, and the older condition is retained in Larix and Psezedotsuga. The number of ovules per carpel is also constant at the symmetrical minimum of 2 , and the cone-scale is dominant in cone-formation, the developing seeds being protected by the overlap and mutual growth-pressures of these scales, which subsequently again diverge to allow the dispersal of the seeds. Pinus alone attains the sealing mechanism of the apophyses, though Cedrus is also a 2 -season cone. It is clear that a one-season cone is the normal case (Picea, Larix, Abies, Tsuga), and the peculiar precocity of the cone-scale in Pinnts also obtains in Picea, Tsuga, and C'edrus; though any special efficiency in pollination remains doubtful, since in Larix, Pseudotsuga, and Abies the bract-scales are still effective as pollen-catching members. In the latter again the bract-scale may remain prominent in the adult cone, thus enhancing its original significance, as also possibly its original morphological differentiation (Pseudotsuga). The precocity of this 'cone-scale' formation is apparently connected with rapid sealing of the cone afier pollination, in its perennating stage during the growth of the sexual individuals.

The small wind-dispersed seed with cone-scale slip for 'wing' is constant for all as an efficient mechanism, and the older condition of shedding cones, and even scales (=carpels), in Cedrus, Abies, Psendolarix, of which vestigial traces may be traced in Pinzus, is still dominant in these more archaic types. The vertical orientation of cylindrical cones is also the simplest case, as involving only one geotropic correction $\left(-^{\mathrm{ve}}\right)$, Abies, Cedrus; inversion (P'inus, Picea) is secondary, and requires a clear internodal extension in the cone-stalk, the lack of which results in eccentric development in many l'ine-cones.

Theory of Taxodineae: Among the few surviving types of this series it will be noted that specialized foliage-needles give place to more elementary reduced scale-leaves (Sequoia, Cryptomeria, Arthrotaxis). Radial symmetry and indefinite production of laterals is the rule; winter-buds may be wanting (Cryptomeria); dorsiventral foliage and shoot-systems (Sequoia scmpervirens and Taxodium) may be associated with advancing spur-organization, the first indications of which are traced in Segrioia gigantea: yet Sciadopitys passes on to a stage with a monophyllous bifoliar spur-formation in false whorls, even beyond the condition of the 2-needled Pines; showing that a type which may remain elementary in one respect may be highly organized in some other.

The flowers also present more generalized factors, though all are small and much reduced; the pollen-sacs are typically more than 2 per stamen $(5-6)$, and the ovules similarly per carpel (I0). None attain to winged pollen, and the cone-scale region is never functionnl in the stage of pollination. The simplest ovulate flower is presented by Cryptomeria, with erected ovules exposed in what is little more than a spiral bud-construction.

The cone-scale is only significant in the formation of the green-cone, as a crested outgrowth of the bract-scale, carried up by intercalary extension to seal the scales, otherwise rudimentary and ineffective. There is no secondary inversion of the cones, but separation of the scales on desiccation is normal; nor are the scales shed indiviclually.

The seeds are small, but in all cases any 'wing'-extension is due to the testa, and there is no wing-slip cut off the cone-scalc. Cryptomeria appears as the most generalized and archaic type of the series, because it presents the least number of factors of secondary specialization. 
CUPRESSINEAE : a conventional series of Conifers (ro), characterized by small whorled, foliage-leaves, and small whorled cones of simple organization; the most familiar being Cupressus (I5), Thuya (5), Juniperus (35). Others are forms more particularly of the southern hemisphere (Callitris, I5); Libocedrus (8) ranges from New Zealand and Chili to California and Japan; the finest trees follow the Pacific Slope (Cupressus, Chamaecyparis, Thuya), but Cupressus and Juniperis are common forms of the Mediterranean region. Fossil forms with the extreme specialization of Libocedrus are described from the Cretaceous.

As one of the simpler available types (B.G.O.) may be taken:-

Cupressus Macnabiana, a shrubby species, California, ro-40 ft., and I ft. diam.

Branch-system based on decussate phyllotaxis and small closely adpressed scale-leaves; no bud-scales. Foliage-shoots green, leaves $2 \mathrm{~mm}$., with central resingland, spaced on main shoots by internodes of ro $\mathrm{mm}$. Ramification from axils of a few, with no special rule, $\mathbf{I}-\mathbf{2}$ at a node; divergent in all directions: slightly compressed in the plane of 2 rows, but no other dorsiventrality. Current year's growth green; scale-leaves functional for $2-3$ years; smooth bark in 4 th ; laterals similarly

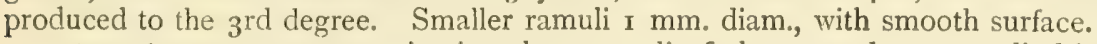

Staminate flowers terminating short ramuli of the second year; cylindrical or 4-angled; of 12 scales, each with 4 pollen-sacs : pollen spherical, not winged.

Ovulate fiower, similarly situated, small, $3 \mathrm{~mm}$., of 6-8 scales, decussate, divergent, displaying numerous erect ovules with micropyle and drop-mechanism; about 40 ovules ( 10 per scale) seen from above. Pollination in March; scales close over ovules to green cone. Fertilization in June. Cones ripened in Oct., as spherical woody structures, $\frac{3}{4}$ in. diam., of 8 scales, close-fitting by margins ('valvate'), of $4^{-5}$ angled facets, with central spinous process $(2 \mathrm{~mm}$.). Remaining on tree I-2 years; usually not opening: intended to diverge and scatter small seeds $(2 \mathrm{~mm}$.) with 2 lateral wing-edges, brown. Embryo with 2 cotyledons. Juvenile leaves acicular.

C. sempervirens, Mediterranean Cypress, with similar foliage and habit; cones I in. or more long, of 8-14 scales. Ultimate ramuli I mm. diam., leaf-scales with sharply pointed tips adpressed on old shoots, divergent on younger ones.

C. macrocarpa, Monterey Cypress, the finest form; $70 \mathrm{ft}$, and $6 \mathrm{ft}$. diam., old trees table-topped; similar branch-systems spreading in all directions. Cones $I_{2} \frac{1}{2}-2$ in., light brown, ellipsoidal, with massive valvate scales : cotyledons $3-4$. Ultimate ramuli stouter, $\mathbf{I} .5 \mathrm{~mm}$. diam.; leaf-scales broadly ovate, adpressed, with indistinct cyst and two longitudinal grooves.

Cupressus (= Chamaecyparis) Nootkatensis, Sitka Cypress, forest-tree of British Columbia and Alaska; I $20 \mathrm{ft}$, and $5 \mathrm{ft} .6 \mathrm{in}$. diam., more specialized in shootorganization, but with reduced cones (ovules only 2 or so per scale).

Branch-system: Similar decussate foliage-scales, and absence of bud-scales. Main leaders flexuous: lateral leaders to the $4^{\text {th }}$ degree are formed only from leaves of 2 flanking orthostichies, giving a system thus extending in one plane, as pinnated ramuli alternating at nodes of even numbers, to give 'dorsiventral ' frondose systems (phyllomorphs) resembling compound leaves, and similarly deciduous (by 'cladoptosis') after $3^{-4}$ years. First year's stem green, 2 nd year with red-brown bark, 3 rd with grey-brown (more or less); $4^{\text {th }}$ and 5 th with smooth rind and little trace of scales. Ramuli of and and 3 rd degree flatten in the same plane, as phyllomorphs in 'leafmosaic'. Laterals of first degree at intervals of $2-4-6$ nodes : of second degree at $2-4$; of third degree at 2 (or 'at every other node on opposite flanks'); with characteristic omission of ramuli along basal regions of each degree to suit the leafmosaic. Laterals of the second degree shed in the $4^{\text {th }}$ year or so.

Staminate flowers borne on the ends of ramuli in second season, yellow, $3 \mathrm{~mm}$., of $\mathrm{IO}-\mathrm{r} 2$ stamens, each with 3 pollen-sacs; fully formed in Dec.; pollination in March : pollen spherical.

Ovulate cones similarly situated on different shoot-systems, matured same year as small cones, I $2 \mathrm{~mm}$. diam., of 4 fertile scales, and total of IO-I 2 seeds, $2-3$ per scale ; shed in autumn. Brown cones of 4 divergent cruciate scales, each with central spine and prominent seed-scars, characteristic: seeds flattened, $5 \mathrm{~mm}$. broad, with wing-margins : cotyledons 5. Primary leaves linear; $\mathrm{I}$-inch stem in Ist year; growth about one foot a year. 
Cupressus (= Chamaecyparis) Lawsoniana. Forest-tree, Oregon, $200 \mathrm{ft}$., and 6-I 2 ft. diam.; most variable, 48 vars. recognized (Kew); similar in general organization to preceding.

Annual shoot: flexuous or erect, with dorsiventral habit throughout. Laterals of $\mathbf{I}-4_{\text {th }}$ degree, all produced at alternate 2 nd node (some may be suppressed, but not 4 nodes between). Leaves closely adpressed, with translucent oval resin-gland. Ramuli compressed: Phyllomorphs flexuous, horizontal, or ascending; orientated

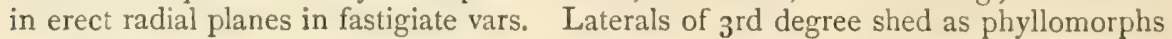
in $4^{\text {th }}$ year.

Staminate flower, with crimson pollen-sacs, 3 per scale; exposed during winter, functional end of March.

Ovulate flower, small, violet-green, usually on separate branches, of 8 scales, two last rudimentary; ovules 2 (or more) per scale. Closed green cone $(8 \mathrm{~mm}$.), with waxy bloom; ripening in autumn, with divergent scales (8-ro); pale, dry, and wrinkled: seeds, about $20 ; 4 \mathrm{~mm}$., broadly winged; cotyledons 2 : dead cones dropped in spring.

Seedling, with juvenile acicular leaves $(5 \mathrm{~mm}$.), growing $\mathrm{I}-2$ in. in first season: annual increment $\mathrm{r}-2 \mathrm{ft}$. per season.

Note. (I) Remarkable for tendency to 'sport', as seedling- or bud-variations: giving rise to 'forms' (which do not come true to seed), distinguished by habit of laterals, variations in relative dimensions of leaf and internode, amount of chlorophyll, wax, \&c. (as fastigiate, filiform, compacta, pendula, nana, forms; as also alba, variegata, aurea, lactea, versicolor ; and combinations). Nuch confusion may be caused by treating such cases as 'species', and giving them names without experimental observation of seedlings (cf. Ulmus, Salix). Bud-variations and special forms are propagated by grafting on the type: but laterals (D.V.) give poor plants.

(2) Forms of 'Cupressus (Japanese) with permanent 'juvenile' stage as small acicular leaves, arranged in phyllomorph-systems of similar habit, are included as Retinospora-forms: may be propagated by grafting.

(3) Phyllomorphic species with 2 ovules per scale may be isolated as Chamaecyparis (genus or sub-section).

Theory of Cupressineae: In the simple scale-leaves, with median V.B. only, and in simple wood-anatomy (no resin-ducts in wood, ray-tracheides sporadic, simple pitting of M.R.P.), these forms suggest a very elementary and divergent type of Conifer. But the symmetrical advanced phyllotaxis (in whorls of 2,3 , or 4 ) is often combined with extreme specialization in D.V. shoot-systems, giving phyllomorphic branch-systems in a manner beyond anything in other Pinoids. Leaf-mechanism is otherwise reduced to the simplest terms, and is seen at best only in recapitulatory juvenile leaves of the Juniper-type.

The flowers express minimum reduction in size, but the pollen-sacs are normally more than 2 per stamen, and the ovules more numerous per cone-scale; only in special cases (Thuya, Chamaecyparis) does the cone reduce to a few ovules and a minimum of scales: Libocedrus presents a limit of 2 scales and $r-2$ seeds per scale. None attain winged pollen.

An entirely new departure is seen in Jumiper (sp.), in which the succulence of the green cone is emphasized, to the extent that bird-dispersal may replace wind. In these cases the cone reduces to a further minimum of $I$ whorl of scales (3) and 3 seeds; the new formations are largely basal and intercalary as in a syncarpous ovary; but the structure is only effective after pollination. In extreme cases ( J.drupacea) the differentiation of sclerocarp and sarcocarp imitates a drupe-type of fruit, I in. diam.

In the simpler types the 'valvate' appearance of the cone-scales is seen to be the result of secondary growth of the original bract-scale (carpel) on both upper and lower surfaces. In Thuy a the first trace of this new growth appears as a crest following the margin of the scale, rather than as an axillary formation; the scales being 'sealed ' by the interlocking papillose surfaces. Such cones are so far the most elementary among Conifers, suggesting the origin of the 'cone-scale' as a secondary extension for the purpose of sealing the cone after the pollination of normally erect axillary ovules with conspicuously exposed drop-mechanism; these being the simplest ovulate floral mechanisms of the series. 
THUYA (Thuja, incl. Biota) 5-6, trees of Cupressus-habit, with similar phyllomorphs; cones small, elongated, with scales obviously overlapping (imbricate), as indicating so far an older phase of the Cupressus-type ; but with few scales and few seeds per scale, and so far specialized.

Type Thuya gigantea (=plicata): forest-tree of Oregon and California, $200 \mathrm{ft}$., to $12-15$ diam. at base. Leader and laterals flexuous, the latter commonly ascending; phyllomorphs flexuous or drooping. 'White Cedar.'

Shoot-system, phyllotaxis decussate as preceding, with D.V. specialization; Laterals of Ist degree at intervals of 8-Io nodes; of second degree at $6-4$ nodes; of third degree at $4^{-2}$, and ultimate ramuli at every other node in alternate sequence. Phyllomorphs of second laterals, 5 in. by $2 \frac{1}{2}$, flexuous or horizontally displayed; with similar suppression of ramuli on lower margins and at base; end-laterals erected: leaves with narrow cyst and convex margins to flanking series. Internodal extension $5^{-8} \mathrm{~mm}$.

Staminate flowers terminate short ramuli of preceding season, towards the basal region of the annual growth: small, $3 \mathrm{~mm}$., of $5^{-6}$ pairs of stamens; pollensacs $3^{-4}$; pollen, spherical, $3 \circ \mu$; connective-flap dark-brown, conspicuous.

Ovulate flower of 6 pairs of scales; terminals ( $\mathrm{I}-2$ pairs) rudimentary and sterile, 3-4 pairs fertile, with 2 (3) ovules per scale: Pollination March (second week); drop-mechanism efficient; flowers located near tips of annual shoot system of previous season, and erected. Fertile scale rapidly elongated in green cone $\left({ }_{5} \mathrm{~mm}.\right)$; the latter erected whatever the presentation of the phyllomorphs, slender, $5 \mathrm{~mm}$. diam.; scales fused by interlocking papillose ceils of a special crested growth of the upper surface.

Adult cone matured in same season; scales diverge and seeds shed (Oct., Nov.), gone by Dec.: sceds $4 \mathrm{~mm}$., with lateral wing-extensions: cotyledons 2 ; seedling with acicular juvenile leaves; laterals assume the D.V. habit.

'T. occidentalis, Arbor Vitae, 50-6o ft., N. Amer. Eastern States (I596); of similar growth: first laterals at long intervals (8 nodes); older scale-leaves with prominent resin-cyst : cones of 4 fertile scales, 2 ovules per scale, $\frac{1}{2}$ inch long; seeds winged, $3-4 \mathrm{~mm}$.

T. orientalis ( = Biota), China, $50-60 \mathrm{ft}$; ; commonly planted as shrub in several varieties; fastigiate habit with phyllomorphs orientated in radial plane of tree; to be distinguished from fastigiate Chamaecyparis Lawesoniana; laterals at 4-6 nodes on main leaders; phyllomorphs of short and slender $(\mathrm{I} \mathrm{mm}$.) ramuli. Staminate flowers abundant, of 3 pairs of stamens, yellow; pollen-sacs $3-5$; pollen spherical, $30 \mu$. Ovulate flowers on upper margins of phyllomorphs, of 3 pairs of scales, uppermost large, divergent, sterile; ovules $2-1$ per scale; typically 6 in all, in characteristic pattern as seen from above, varying 6 fertile scales and ro ovules: Pollination March, second week; green cone large, ovoid, $20 \mathrm{~mm}$, with waxy bloom, erected; dehiscent in autumn while scales are still semi-succulent, shrivelling up later; seeds large, ovoid, $5^{-6} \mathrm{~mm}$., without wing; cone-scales with reflexed horn-like tip; a very distinct type: cf. argentea, aurea, compacta, gracilis, pendula, \&c., forms.

Note, in all phyllomorphic species Retinospora-forms, with acicular juvenile leaves retained on the frond-systems, may occur.

Also known as 'White Cedar', an important timber-tree of California, confused as Thuya gigantea (Hort.), and commonly planted, is Libocedrus decurrens, a T'huya-form, $150 \mathrm{ft}$. and 7-8 diam., with broad fan-shaped phyllomorphs, 4-6 in., spreading or drooping. The foliage-system is readily distinguished by the 'decurrent' flanking scales, which run along the margins of the D.V. series throughout their course. Ramification much as in preceding, and flowers very similar at ends of ramuli. Staminate flowers, $6 \mathrm{~mm}$. long, in great profusion (golden effect) of 6-8 pairs of stamens, pollen-sacs $3^{-4}, \mathrm{I} \mathrm{mm}$., pollen $30 \mu$. Ovulate flower of typically $4^{-6}$ pairs of divergent scales, the penultimate pair alone fertile, with 2 ovules per scale; in this respect presenting the limit of symmetrical reduction of the ovulate system. Cones erecting and increasing to $\frac{3}{4}-\mathrm{I}$ inch, of 2 main fruiting scales clapped together on end-rudiments, and diverging to discharge 4 seeds, each with oblique wingextension twice as long as seed, $20 \mathrm{~mm}$. over all. Cots. 2 ; seedling with acicular juvenile leaves. 
JUNIPERUS (35). Northern types, widely distributed. Maximum in subtropical regions; trees and shrubs of Cupressoid habit, but the phyllotaxis varies to whorled trimery, and the small 'cones' remain succulent ; the scales fuse up more or less, and tend to become non-dehiscent and bird-dispersed 'berries': often dioecious : the limit of Cupressoid specialization in 3 distinct sub-sections equivalent to genera.

I. Juniperus sinensis (= chinensis), $60 \mathrm{ft}$. tree, Himalya, Japan.

Shoot-system, trimerous or dimerous, varying on the same branch; with heterophylly; leaves acicular with waxy bloom (and stomatal tract on upper side), glaucous, $8 \mathrm{~mm}$., with sharp points; also decussate and adpressed (Cupressus-type) or trimerous, all on the same shoot.

Staminate flowers, abundant, on ramuli of previous season, formed in autumn, functional in March, $6 \mathrm{~mm}$.; stamens $7-8$ pairs, pollen-sacs 4 , connective-flap yellow; pollen, spherical, $3 \circ \mu$ : output enormous on staminate tree.

Ovulate flower ( $=J$. sphaerica), small, green, decussate, with 2 uppermost scales sterile, typically 4 ovules, 2 per scale, as in preceding, varying 6 : closing after pollination to green cone with white waxy bloom (ro $\mathrm{mm}$.) of irregular shape. Seeds ripened in autumn; cones dry and shrivelled by Dec.

II. Juniperus communis, $4 \circ \mathrm{ft}$. tree, indigenous as reduced dwarf (nana) form on mountains, little more than $8 \mathrm{in}$. high; leaves all acicular, to $\mathrm{mm}$., sharp-pointed and trimerous, functional 3 years; no D.V. organization in shoot-system. Dioecious.

Staminate flowers of $5^{-6}$ whorls of 3 , pollen-sacs $3-4$.

Ovulate flowers, trimerous, terminating short ramuli of $6-7$ whorls of scales; only the upper 3 scales alternate with 3 erect ovules, fusing up in green cone by basal intercalation.

'Berry' ripened in second year, glossy, $8 \mathrm{~mm}$., like black currant, with blue waxy bloom. At apex triradiate mark of 3 adpressed scales with papillose epidermis. Pigment in epidermis only; seeds $3,5 \mathrm{~mm}$., with strongly sclerosed testa. Birddispersed. Cotyledons 2. Seedling with acicular juvenile leaves, decussate for Ist and 2 nd year. The most advanced of the series: acicular leaves express a retention of more ancestral stage (otherwise 'juvenile'); trimery is a secondary departure; the succulent fused cone follows as the last expression of the Biola-J. sphacrica sequence. For bird-dispersal and anthocyan-pigmentation, cf. Taxus: for copious production of short spur-shoots, giving a dense tufted habit to the foliage-system, cf. Cedrus.

$J$. Virginiana gives 'Pencil Cedar'; J. communis berries 'Gin' (Genévrier).

Comparison of Phyllomorphic Cupressineae.

I. Chamaecyparis Nootkatensis; Last Phyllomorphic ramuli $2 \mathrm{~mm}$. broad, scales acuminate, claw-like $(2 \mathrm{~mm}$.) with no translucent resin-cyst, only a slight median keel on D. units: Internodal extension Io $\mathrm{mm}$.

2. Chamaecyparis Lawsoniana; ultimate ramuli little over $\mathbf{I} \mathrm{mm}$. wide; scales with blunt apices (and very minute mucro) and boldly waved diagonal curves: Resin-cyst broadly elliptical or sub-spherical; most translucent and conspicuous (esp. in sunlight). Internodal extension ro-20 mm. (40 on pendulous leader).

3. Thuya gigantea; ultimate ramuli much compressed, $2 \mathrm{~mm}$. broad; green scales of lateral series with marked mucronate tips and rounded convex margin. Resin-cyst narrowly elliptical and less translucent. Internodal extension $10 \mathrm{~mm}$.

4. Thuya occidentalis; similarly compressed, with shorter ramuli; apices acute; resin-cyst prominent and projecting at the surface. Internodal extension ro $\mathrm{mm}$. On main phyllomorph axes the resin-cysts appear as small blisters, and a scale may show I-2 accessory lateral ones. Foliage usually bronzed in winter.

5. Biota orientalis; Phyllomorphs in vertical radial planes; ultimate ramuli, short, I mm. broad; marginal scales with more or less irregularly straight outline. Cyst ill-marked, narrowly elongated. Internodal extension $5^{-10} \mathrm{~mm}$.

6. Libocedrus decurrens; Phyllomorphic ramuli much compressed, $I-I \frac{1}{2}$ in. long, and $2 \mathrm{~mm}$. broad: apices of flanking members appearing at same level as D.V. series, and so 'decurrent' along their entire course: tips acute; resin-cyst only vaguely translucent.

7. Retinospora-forms; phyllomorphs with small acute acicular leaves, throughout, not adpressed, and more Fern-like in appearance; as persistent juvenile phases (sports) of Cupressus, Thuya, and Biola; cf. Retinospora obtusa as from Chamaecyparis pisifera, with branch-reversion. 
An isolated section of forest-trees of the Southern Hemisphere, S. America, Australia, New Zealand, and Pacific Islands: Araucaria (incl. Eutacta) ro, Agathis (incl. Dammara) 4 ; very imperfectly known, and probably in several generic types.

I. Araucaria imbricata (Monkey Puzzle), Forest-tree, Chili, 50-100 ft., and 3-5 ft. diam., pyramidal and stiff when young; laterals pendulous by weight, and ends erecting later: no spurs, no bud-scales, essentially tropical and sub-tropical; alone grown out of doors in this country. Laterals in a false whorl $(5-7)$ each season; laterals of second degree at uneven distances, assuming more or less dorsiventral habit. Leaves as broad scales $(\mathrm{I}-2$ in.) with many V.B. (distinct type); functional for Io-r 5 years, traces for many more; leaf-pattern as transverse scars on bark for 50 . Dioecious, varying to monoecism.

Staminate flower, enormous strobilus, largest in Conifer series, often formed in abundance, from axils of scales, without rule, erected, 6 in. by 2, persisting for more than one year; stamens 500-600, in spiral series, with long acuminate connective apex ( $15 \mathrm{~mm}$.), reflexed later: pollen-sacs (6-9), I $2 \mathrm{~mm}$. long, from distal end of anthers, partly free: pollen, spherical, $50 \mu$ diam., not winged. [In $A$. brasiliensis, 6 in. long, of 1000 stamens, pollen-sacs Io-15, pollen-grains 500-1000; total output of microspores of one flower approx. ten millions.]

Ovulate flower, a clustered massive bud-growth, 3 in., of acuminate bractscales with slender tips upwardly directed; ovule one per scale, inverted; cone-scale vestigial, as rudimentary 'ligule' at base of ovule. Pollinated June (England); green cones erect and increasing to spherical form; fertilization in second summer; seeds matured in third summer. Data for Chili not known. [Details from $A$. brasiliensis : pollen deposited on cone-scale (ligule), \&c., before ovules are fully formed; germination to branched filaments, like spider's web, with haustorial tubes in tissue of scale and axis, ultimately penetrating nucellus 6 months after pollination. Pollen with many prothallial nuclei.]

Adult cone, 6-7 in. diam.; no special growth externally or cone-faceting; bracts fuse completely with integument. Ripe cone falls to pieces, leaving axis and basal 'perianth' of sterile scales: no wing-formation; 300 seeds per cone. Seed very large, $40 \mathrm{~mm}$. by $\mathrm{I}_{5}$ diam. : embryo $30 \mathrm{~mm}$.; cotyledons 2 ; endosperm stores starch. Germination hypogeal; first-year seedling 4-5 inches. Seed edible; note exudation of white resin on trunk.

A. brasiliensis, forest-tree of S. America, $150 \mathrm{ft}$., exploited; more slender leaves, 2 in. ; staminate flower $4-6$ in.; cone $6-8 \mathrm{in}$. diam., with close-fitted facets of scales $2 \mathrm{r}: 34$ seriate, $20 \mathrm{~mm}$. wide; similarly falling to pieces; seed $40 \mathrm{~mm}$., sunk in scale-base.

A. excelsa (= Eutacta), Norfolk Island Pine, $180 \mathrm{ft}$., distinct type. Growth very symmetrical; foliage-leaves awl-shaped, laterally compressed, rhomboidal in section; functional for many years (ro). Greenhouse cultivation only; false whorls of laterals conspicuous; ramification to $3^{\text {rd }}$ and 4 th degree, with marked dorsiventrality. Cones $4^{-6}$ in. diam., spherical and pendulous; scales $I_{3}: 2$ I seriate, with rhomboidal facets 3० $\mathrm{mm}$. Germination epigeal. A damaged apex regenerates a symmetrical leader.

A. Bidwilli (Bunya or Bon-yi), I50 ft., valuable forest-tree of Queensland; symmetrical habit, leaves 2 in. long; staminate strobili abundant, erected, 6 in. long, by $\frac{1}{2}$ in. wide; monoecious: Fruiting cones globose, up to 12 in. by 9 , scales 4 in. by 3 , and cone as much as Io lb. weight (green); woody rhomboidal scale-facets with 'ligule' showing at apex (in manner of Taxodineae), and tips of bract-scales reflexed; seeds $40 \mathrm{~mm}$., fused with broad scale. A fine type, seeds edible.

A. Cunninghamii (Hoop Pine), $200 \mathrm{ft}$., and $4 \mathrm{ft}$. diam., growing in forestassociation New South Wales, and a valuable timber-tree. Bark in characteristic 'hooped' bands. Leaves acicular, ro-25 mm., pectinated on laterals. Staminate flowers 3 in. ; fruiting cones 4 in. by 3 , apex of bract-scale rigid and reflexed.

II. Agathis australis, Kauri Pine, N.Z., attaining $\mathrm{I} 50 \mathrm{ft}$. and $20 \mathrm{ft}$. diam., cylindrical bole and spreading branches, leaves $2 \frac{1}{2}$ in. by $\frac{3}{4}$ : monoecious. Staminate flowers $\mathbf{I}-2$ in. ; stamens with $5^{-1} 5$ long pollen-sacs: ovulate flower of bract-scales, $20 \mathrm{~mm}$. diam., one ovule per scale, inverted, with no distinct 'ligule'; but cone-scale rudiment apparently wholly fused up with bract-scale, and traced in V.B.-distribution, 
and suggested area on cone-face. Pollen-grains germinate in the axils of the scales, with haustorial growths: fertilization 13 months after pollination, and seeds matured in 4 more. Adult cone $2-3$ in. diam., round and woody, falling to pieces; seeds ro mm., free, with broad unilateral wing: cotyledons 2. Exploited for gum-resin.

A. robusta (Dundathu Pine), i $50 \mathrm{ft}$., and to $8 \mathrm{ft}$. diam., most valuable Queensland timber-tree: leaves $4^{-6}$ in. and I broad, lanceolate or ovate, spirally arranged, pectinated on laterals. Cones $5 \mathrm{in}$. by 4 ; seeds with unilateral wing. A fine tree with columnar trunk and spreading branches, gum-resin dries black.

Dammara orientalis, on mountains of MIolucca Is., a large tree, Ioo ft.; leaves $2-4$ in., and $\mathrm{r} \frac{1}{2}$ wide, pectinated in 2 series; dioecious; cones 4 in. in diam., with distinct effect of 'cone-scale' on cone-facet.

Timbers: Araucaria imbricala, annual rings $5 \mathrm{~mm}$. broad, wood without resinducts, all the MI. rays uniseriate; pitted tracheides with bordered pits in $\mathrm{I}-2$ rows, close-set, in patches near ends of tracheides; when 2-ranked the border assumes an effect of 'hexagonal' packing. M.R.P. with contracted and attenuated ends, thin walls on all sides, pits flared and bordered, large, $2-7$ per tracheide.

A. excelsa, tropical, with no demarcation of rings; tracheides with bordered pits close set $\mathrm{I}-2$ (3) rows. M.R.P. thin walled, contracted ends, with small oblique or flared pits, close set and bordered, 2-9 per tracheide.

Agathis australis, finest timber, tracheides full of resin 'bars', rings feebly differen. tiated, $2 \mathrm{~mm}$. Bordered pits in $2(\mathrm{r}-3)$ rows, close set. M.R.P. $2-6$ per tracheide, small, flared and bordered. Pits on tangential walls of summer-wood.

TAXOIDS: Coniferae are conveniently classed in two main groups as (1) Pinoids, with typically dry 'cones' and wind-dispersed seeds; (2) Taxoids, in which the seeds are solitary, more or less succulent, and dispersed by birds. The case of Juniperus communis shows how a similar biological adaptation may be perfected in the Cupressineae series; and indications of spiral cone-aggregation may be found in Taxoids (Saxegothea). While the Pinoids (Pinaceae) are taken in four main series, the Taxoids (Taxaceae) are conveniently separated into two, according as the ovules are erect (Taxus) or inverted (Podocarpus). Pollination as before is typically by a drop-mechanism (Taxus), but may be superseded (Saxegothea).

Special interest centres in Podocarpus (6o sp.), as a great race of forest-trees of the Southern Hemisphere (Australia and New Zealand), very imperfectly known; strays extending to Pacific Coast, tropical mountains, Africa, E. Indies, China, and Japan: the genus practically corresponds in the S. Hemisphere to Pinus of the North Temperate forest-zone, and presents the case of the type of Conifer most widely divergent from Pinus in many respects. Usually dioecious; timber corresponding with that of Taxus; pitted tracheides with tertiary spiral thickening: foliageleaves spiral on erect shoots, D.V. and pectinated on laterals ( $P$. japonica), with one median V.B., and one median duct. Staminate flower of small stamens, spirally arranged, each with 2 pollen-sacs; dehiscence longitudinal, and pollen-grains winged in the manner of Pinus. Ovulate flower remarkable, the ovules being borne solitary in the axil of functionless reduced bract-scale, on an elongated inflorescence-system $(P$. spicata), or reduced to $2-\mathbf{I}(P$. Totara), anatropous, with 'two integuments': the inner delimits the micropyle, and becomes a sclerotesta; the outer, succulent, turns red later, and edible more or less to birds, \&c. Special case in P. Totara, $60 \mathrm{ft}$., T'ótara Pine, New Zealand, with dark-red mahogany-like wood; the inflorescence-axis below $2-1$ ovules becomes succulent, enlarged like cherry with projecting 'stone', hence generic name. P. elongata of S. Africa with habit of Kauri.

Comparison of Leaves of Taxoids.

I. Taxus baccata, needle $\mathrm{I}-2 \mathrm{in}$. and $2 \mathrm{~mm}$. wide: one central bundle, no ducts, no endodermis, no sclerosed hypoderm: palisade $x-2-3$ rows, wanting in shade-leaves: guard-cells lignified, in stomatal tracts on lower surface (6 cut in each); subsidiary-cells with papillose knobs; transfusion-tracheides as wing-extensions, with reticulated thickening and pits.

II. Podocarpus japonica, leaf $2 \frac{1}{2}$ in. and $4 \mathrm{~mm}$. wide; D.V. generalized type; upper epidermis aqueous, with thick outer wall; palisade $2-3$ rows deep; one central V.B., and one associated duct on lower surface. Transfusion-tracheides as prominent wing-extensions, with reticulated thickening: stomatal tracts on lower surface, about 15 stomata cut in each. 
TAXUS (in possibly 7 geograpical races). Isolated type of N. Temp. Forest-tree with general Conifer-habit, but no cones; ovules solitary, with succulent seed investment ('aril'); dispersed by bird-agency.

Type Taxus baccata, Yew, 8o ft., and diam. to $6 \mathrm{ft}$., age to 1500 (B.G.O., $30 \mathrm{ft}$. and 300 years). Indig., Central and S. Europe to Himalaya. Growth slow.

Annual shoot; leaves as flat needles $(\mathrm{I}-2$ in.) spirally arranged on erect shoots (cf. fastigiate form, 'Irish Yew'), dorsiventrally pectinated in 2 rows on laterals. No other D.V. shoot-construction; laterals in axils of leaves of previous season, few, without rule, freely produced when shoots are cut back, hence use in topiary work. Dioecious (with rare monoecism).

Staminate flowers similarly in axils of previous season, without rule, abundant, turned to lower surface below needles; $10 \mathrm{~mm}$., perianth of distinct scales, larger upward, 2 last often prominent ( 5 as full cycle); distinct floral internode ( $3 \mathrm{~mm}$.), stamens few ( $\left(5_{5}-\mathrm{I} 6\right)$, as peltate sporophylls with $5-9$ pollen-sacs; pollen small round, $25 \mu$; with 'smoke-effect' as light grains rise in air. Pollination Jan., Feb.

Ovulate flower a reduction-limit; special short shoots of spirally arranged scales $\left(8-\mathrm{I}_{3}\right), 2 \mathrm{~mm}$. over all, similarly borne in leaf-axils and deflected to lower side ; each bears I (-2) lateral axes of a few (6) scales enclosing a terminal ovule, the latter taking the end-position, with exposed micropyle only, and conspicuous drop-mechanism. Wind-pollination effective; ovules enlarge to green 'berry' structures, enclosed in secondary growth of a green collar-investment ( $=$ 'aril'), with special protective function (summer), dilating and ripening Sept.

Adult seed, ovoid, ro mm. by 8, included in bell-shaped aril, enlarged and dilating at end, bright red, succulent, sugar-storing; pigments anthocyan and residual carotin (cf. yellow-fruited var.). Taken freely by thrushes, \&c., in Nov. (usually all stripped by Dec.). Testa differentiated, $6 \mathrm{~mm}$., stony sclerotesta; endosperm with fat-storage ; embryo small, 2 cots.

Note: slow growth and great shade-endurance; spiral bud-galls by omission of internodal extension and D.V. mechanism (Cecidomyia Taxi); Fastigiate var. also with omission of D.V. organization, (Irish Yew) carpellary sport, but others staminate.

GINKGO BILOBA, important monotype, as representative of oldest series: roo ft., China, Japan, and in cult. (= Salisburia adiantifolia, Maidenhair tree): combines distinct factors as a unique survival; fertilization (Cycad), stem (Conifer), fruit (Taxoid), foliage (Fern). The only tree with motile male gametes.

Annual shoot; leaves spirally arranged, broad $(2-3$ in.), petiolate $(2-3$ in.), wedge-shaped or 2-lobed, with dichotomous venation, deciduous; T-bud with slight crater; developing leaves and all tissues with excess cluster-crystals of calc. oxalate; spurs on second-year shoot in manner of Larix, functional for ro years, $\mathbf{I}$ in. long, rarely branching or becoming leaders; crown of leaves $(3-5)$ each season, and cambium suppressed.

Note bud-scales and leaf-scars, internodes extended I-2 in.; no D.V. habit, laterals ascending at wide angles. Dioecious (rarely flowering in Britain).

Staminate flower; several $(3-5)$ on spur-shoot before the leaves are grown, I in. long; stamens about $5 \circ$, pollen-sacs 2 , pendulous $(2 \mathrm{~mm}$.). Pollen, $3 \circ \mu$, spherical, not winged. Pollination in April, output enormous.

Ovulate fiower, of $\mathrm{I}(-2)$ ovules, borne on long stalk ( $\mathrm{x}$ in.), $\mathrm{I}-8$ on a spur with the young foliage; ovule $2 \mathrm{~mm}$., with basal 'collar'-rudiment; growing to a large 'berry '-structure, size of small green plum; fertilization late in Sept., Zoïdogamic; antherozoids 2 from 'pollen tube', motile, multiciliated, roo $\mu$ long, free-swimming in pollenic-chamber of nucellus, with 'tent-pole' mechanism.

Ripe ovule over $\mathrm{r}$ in., ripened same season (Nov.), appearance of yellow plum; sarcotesta yellow, succulent; sclerotesta of stone-cells as 'plum-stone'. Embryo with 2 cots., endosperm storing starch; germination hypogeal type; first leaves scale-like, a few normal leaves and terminal bud only as the first season's growth.

Note lack of excessive xerophytic adaptations, beyond deciduous habit; extreme reduction of ovulate scheme, parallel with Taxus only in subsequent developments of ovule in correlation with dispersal by birds. 
Relation of Conifers to other Gymnosperm Series.

Gymnosperms constitute a relatively small but very important central group in the Botany of Land-Flora, as presenting the story of the evolution and establishment of the seed-stage (Archispermae) in dominant land-plants. All are more-or less archaic relics, more nearly related to the horizon of the Fern, with traces of aquatic archegonial mechanism; the groups largely comprise monotypes of special organization, as forms now relegated to inferior biological environment; hence the majority are remarkably xerophytic. Any systematic arrangement still remains wholly provisional. Modern phyla and even some genera may go back with little change to the Cretaceous. Of 7 distinct lines of development, 3 are known only in the fossil state.

Note, the word Gymnosperm is probably only a conventional expression covering the end-terms of widely different phyla, all at a comparable horizon of seedevolution, and running more or less parallel in the progression of gametophytic stages. 'Affinity' within these groups need not be pressed too far, since all Angiosperms must have passed through comparable phases in attaining minimum reduction in their sexual prothallia, with limiting terms of siphonogamy and post-sexual nutrition of the embryo.

The most distinctive feature of their organization is the anatomy of the metaxylem, with tracheides connected by bordered pits on the radial walls only; from this only the Gnetales diverge.

I. Pteridosperms : very Fern-like in general organization, as underwood vegetation, with frond-leaves and definite seed-stages. Fossil only from Palaeozoic (Carboniferous), especially in calcite 'coal-balls': cf. Lyginodendron, Heterangizm.

II. Cordaitineae : Forest-tree types of Devonian and Carboniferous. Timber much as Araucaria: flowers small, more in the manner of Pinus, in compound inflorescences. Leaves large; seeds in strobili, often large. Fossil only, cf. Pitys Withami (Nat. Hist. Mus.) and Craigleith ( 1830$), 47 \mathrm{ft}$. trunk, $\mathrm{I} \frac{1}{2} \mathrm{ft}$. at top.

III. Ginkgoales (I/I); Forest-tree types of Tertiary to Mesozoic: only survivor Ginkgo biloba, with Conifer wood, plum-like seed of Taxoid, and Zoïdogamy; elementary pollen-tube system, pollenic chamber, and 'tent-pole' mechanism.

IV. Cycadaceae (9/80); Plants of underwood or hill-slopes, with mostly monaxial Tree-fern or Palm-habit, to $60 \mathrm{ft}$; tropical and sub-tropical; Frond-leaves bipinnate (Bowenia), usually once pinnate (Cycas), large, 2-6 ft. long. Staminate flower ( $2 \mathrm{ft}$. in Ceratozamia) of spirally arranged stamens (to 500 ), with possibly (to 750 ) hundreds of pollen-sacs, and up to 30,000 pollen-grains in a pollen-sac (Dioön Encephalartos): Anemophilous. Ovulate flowers often immense, $30 \mathrm{lb}$. (Dioön), and 2-3 ft. (Microcycas). Ovules borne on definite Carpels, several (Cycas), or 2 only. Seeds may be as large as eggs (Dioön). Zoïdogamic: microgamete of Dioön, $300 \mu$ diam., 5 coils of ciliated band, and visible to naked eye.

V. Cycadeoideae; Mesozoic plants of dwarf Cycad-habit (Bennettites), to Palmhabit (Williamsonia); cf. Portland 'Fossil Birds' nests' (Cycadeoidea), and Wyoming beds; mostly silicified. Large floral-shoots borne singly in leaf-axils, with perianth, large frondose bipinnate stamens, and ovulate cone for gynoecium: no apparent 'carpels'; probably insect-pollinated.

VI. Coniferae (40/350); Forest-trees of modern epoch; siphonogamic, and anemophilous, with tendency to reduced 'needle' or scale-foliage ; Pinoid cones, and Taxoid arillate seeds. Pinus, Juniperus, Taxus, single species of three limiting cases, alone indigenous.

VII. Gnetales $(3 / 45)$; Isolated relics of a very distinct series approaching Angiosperms in some respects. Ephedra, a switch-plant, with no photosynthetic leaves. Gnetum, a tropical-forest Liana-form, with broad net-veined leaves, and inflorescences of small flowers, possibly insect-pollinated. Welzuitschia extreme desert-xerophyte, of rainless SW. Africa; abbreviated woody trunk, $3 \mathrm{ft}$., with 2 immense foliage-leaves only, growing by basal meristem, and splitting. Inflorescence panicled, ovulate cones ( 2 in.), with winged seeds: Staminate flower with perianth $(2+2)$, staminal-tube of 6 stamens, each 3 pollen-sacs, investing relic of sterile ovule, with drop-mechanism adapted for insect-pollination. Definite relic of hermaphrodite flower in minimum terms. 
A. Comparison of the Leaves of Pinus (sp.); type, $P$. sylvestris.

I. Pinus Pinaster (= maritima); 2-needled spur; leaf large well-differentiated, 5-8 in. ; stomatal lines $\mathbf{I} 2-\mathbf{I} 4$ on flat side, I 8 on convex side; serrations 5 to $\mathbf{I} \mathbf{m m}$.: clean semicircular outline to section, $2 \mathrm{~mm}$. wide. Epidermal cells almost solid; Hypoderm 2-3 deep, thick-walled, interrupted at stomata; guard-cells sunk at base of cylindrical outer chamber $(45 \mu)$, blocked with exudation in old needles. Plicate mesophyll 3 cells deep, palisade-like at surface; good U-cells below stomata : Ducts 2, lateral, of $3-5(7-10)$ in Mesophyll, with one layer of fibrous-sheath, not very thickened: two V.B., separate; well-marked rays; no central fibres; tannin-sacs over phloem, with but slight thickening, as also over protoxylem. Transfusion-tracheides 3 deep over phloem. Massive angles, $\mathbf{1} 50 \mu$ thick. The finest type of Pinus-leaf.

II. P. radiata (= insignis): 3 -needled spur (varying 2), spinous teeth of margin 4-5 per mm.; 4-5 in. long; stomatal lines on 3 sides, 9-1 2 on convex outer, and $4-5$ on radial faces, latter-at angle of $\mathrm{I} 20^{\circ}$; section $\mathrm{r} \cdot 6 \mathrm{~mm}$. broad; differentiation much as preceding: Hypoderm 2-3 cells deep, interrupted at stomata; plicate mesophyll 3 deep; 2 V.B. separate, or nearly confluent; Resin-ducts 2, lateral, in mesophyll ( $\mathrm{I}$ or wanting): Guard-cells sunk $3 \circ \mu$, outer chamber broadly flaskshaped $(35 \mu)$, with outer pore $(\mathrm{r} \circ \mu)$. Plicate cells palisade-like. Central fibres at base only; tannin-sacs over phloem: a small duct occasionally between xylems.

III. P. excelsa; 5-needled spur, leaves slender, 5-8 in. long; marginal serrations irregularly $\frac{1}{2} \mathrm{~mm}$. apart; triangular in section, $.8 \mathrm{~mm}$. wide: stomatal lines $4-5$ on radial faces only, wanting on outer side. Ducts $2(I-3)$, peripheral, on outer face, (exc. in mesophyll). Guard-cells sunk $20 \mu$ only; hypoderm I-2 deep; plicate mesophyll 2 deep. Stele small and circular ( $.3 \mathrm{~mm}$. diam.) with V.B. for the most part undivided. Transfusion-tracheides few, around periphery: albumen-cells distinct. P. Cembra closely similar.

IV. Pinus monophylla; exceptional one-needled spur; leaf 2 in. long, cylindrical; section circular, $2 \mathrm{~mm}$. diam.; stomatal lines about 24 : ducts 2 , lateral, or 6-7 peripheral, spaced round hypoderm; each with $2-3$ layers of small sheathing fibres. Plicate mesophyll 6 layers deep, smaller peripherally, with more marked foldings: V.B. confluent laterally in one line; fibres over phloem, with tannin-content over xylem. Transfusion-tracheides 3 deep; parenchymatous cells of pericycle particularly well marked. A very beautiful leaf.

\section{B. Comparison of leaves of other Abietineae.}

I. Cedus Deodara: Spur many-leaved (20-60); needle 30-60 mm., section rhomboidal, I mm. diam.; stomata on all sides; guard-cells slightly sunk, lignified and covered by subsidiary cells. Epidermis and hypoderm sclerosed; Resin-ducts in contact; fibrous sheath slight. Plicate mesophyll 3 deep with palisade-effect. Stele central, circular, $\cdot 3 \mathrm{~mm}$. diam., with endodermis; 2 V.B. closely approximated, but distinct. Transfusion-tracheides converging on fibres over phloem only, with simple or bordered pits; albumen-cells distinct.

II. Larix europaea: Spurs many-leaved $(20-60)$; needles I in. or more, deciduous: section rhomboidal or bilateral. D.V. organization more marked in primary members (of current year): less sclerosed than preceding. Primary leaves (2 in.) with palisade-effect, and stomata on both sides. Resin ducts 2 , lateral. Small circular stele, $300 \mu$ diam., 2 V.B. closely confluent, few transfusion-tracheides, reticulated.

III. Picea excelsa : no spur-formation; needles $\mathbf{I}$ in. or less; more or less lozenge-shaped in section owing to flattening in vertical plane, I mm. deep, and half as wide: stomata on both sides; guard-cells lignified, sunk $20 \mu$, under conspicuous subsidiary cells: Sclerosed hypoderm, mesophyll with first trace of plication, no palisade, minimum spaces; ducts 2 lateral ( $\mathrm{I}$ or $\mathrm{O})$ : small circular stele $(.2 \mathrm{~mm}$. diam.); 2 V.B. separated by one row parenchyma; a few scl. fibres over phloem; transfusiontracheides few, albumen-cells distinct.

IV. Abies cephalonica: massive needles, $\mathbf{I}$ in. or more, no spur-formation; a generalized type; largest leaves extended horizontally, $2 \mathrm{~mm}$. broad, groove on upper surface, median ridge and 2 stomatal tracts on lower. Epidermis sclerosed, 
and hypoderm of $\mathbf{r}$ layer; 2 ducts, lateral in mesophyll; Palisade on upper surface ( 2 rows), no plication, spongy mesophyll with intercellular spaces: central stele circular $\left(35^{\circ} \mu\right.$ diam.), 2 distinct V.B.; fibres central and over phloem ; transfusiontracheides few and scattered laterally.

A. pectinata closely similar, but less specialized in details (shade-leaves): I in. long, I mm. wide; spongy mesophyll more definitely plicated; 2 ducts on lower surface, peripheral.

V. Pseudotsuga Douglasii : needles of Abies-type, $30 \mathrm{~mm}$. long and $\mathbf{1} \frac{1}{2}$ wide ; grooved on upper surface; hypoderm in patches; palisade on upper surface; central mesophyll with slight plication; 2 ducts peripheral on lower hypoderm: 2 stomatal tracts on lower surface ( 6 cut in each in section): guard-cells sunk $\mathbf{5} 5 \mu$ : Central stele, $250 \mu$, distinct endodermis ; 2 V.B. closely confluent, scl. fibres, transfusiontracheides, and alb. cells as clearly defined groups.

VI. Tsuga canadensis: needles $12 \mathrm{~mm}$. long and 2 broad, of Abies-type, grooved on upper surface, 2 stomatal tracts on lower. No sclerosed hypod., epidermis with very thick outer walls, guard-cells and subsidiary-cells conspicuously lignified; one median duct below phloem; palisade on upper surface ( 2 rows); no plication: stele small, with no distinct endodermis; 2 V.B. closely applied; few transfusiontracheides scattered, and alb. cells.

\section{Comparison of leaves of other Conifers.}

I. Sequoia gigantea: acicular type (4 mm.), section rhomboidal, I-3 $\mathrm{mm}$. wide; epidermis and hypoderm thick walled and sclerosed, stomata on both siles; V.B. one central only, with few scl. fibres on both sides. One median duct over phloem; endodermis not marked; transfusion-tracheides as remarkably extended wings to V.B., with bordered pits; albumen-cells few.

II. Sciadopitys verticillata: 'Double-needle,' 2-pointed, 4 in. long, and $3 \mathrm{~mm}$. broad; deep median furrow, with stomatal tracts, on theoretically upper surface. Stomata with solid papillose subsidiary cells $(45 \mu)$, thick-walled lignified guard-cells; sclerosed hypoderm, mesophyll as palisade, I-2 layers, and loose spongy tissue; 2 V.B. (of theoretical units) widely spaced: endodermis ill-defined; pitted transfusion-tracheides as wing-extensions of xylem convergent on upper side: remarkable branched sclerites; resin-ducts (ro) peripheral; xylems give the upper side.

III. Juniperus communis, acicular needle, ro mm., upper surface flat, with one broad stomatal tract (marked by wax-lines); epidermis and thick-walled hypoderm; palisade chiefly on lower surface: one larger central V.B., and one median duct on lower side; a few scl. fibres over phloem. Transfusion-tracheides as pronounced wing-extensions with reticulated thickening.

IV. Cupressus Lawsoniana, phyllomorphic branches with adpressed foliage scales, dorsal and ventral flattened ( $1 \mathrm{~mm}$.), flanking members rhomboidal in section $\left(\frac{1}{2} \mathrm{~mm}\right.$.); sclerosed epidermis and hypoderm; palisade; median V.B. cut obliquely : guard-cells lignified on inner sides of leaves in protected chinks. Large resin-cyst in axial part only; no endodermis; transfusion-tracheides on flanks of xylem, considerably developed in $\mathrm{D}$ and $\mathrm{V}$ members.

V. Araucaria imbricata; Hard leaf, not a 'needle'; row of V.B. across centre, alternating with resin-ducts: Hypoderm of isolated scl. strands; no plicate mesophyll; stomata on both sides, guard-cells sunk $3 \circ \mu$; palisade on both sides; sclerites large and massive with calc. oxalate crystals in wall; transfusion-tracheides as convergent wings of V.B., relatively more developed in smaller bundles, of cells with bordered pits.

VI. Araucaria excelsa, acicular type, rhomboidal in section, to $2 \mathrm{~mm}$. diam.; or laterally compressed: stomata on all sides; central series of $5-\mathrm{I}$ V.B. (one being median) as reduction-limit of a D.V. lamina, not a 'needle': Ducts between the bundles and others peripheral, in the limit one median: Sclerites with Ca. ox. rhombs; transfusion-tracheides often more than the normal xylem.

VII. Agathis australis; lamina with D.V. construction, palisade on upper surface and stomata only on lower. Epidermis aqueous, with outer wall ro $\mu$ thick; hypoderm of tannin-cells and scl. fibres scattered, more on upper surface, and over $\chi$ and $\phi . \quad$ V.B. in median series, small; resin-ducts alternating; transfusion-tracheides inconspicuous, lateral. Stomata sunk $20 \mu$ in cup of subsidiary cells, guard-cells sclerosed. 
- 


\section{OXFORD BOTANICAL MEMOIRS}

Edited by A. H. CHURCH, M.A.

I. THE BUILDING OF AN AUTOTROPHIC FLAGELLATE, by A. H. Church. I9I9. Pp. 27.

2s. net.

2. GOSSYPIUM IN PRE-LINNAEAN LITERATURE, by H. J. DENHA, M.A. I9I9. Pp. 24, 4 text figs. - 2s, net.

3. THALASSIOPHYTA AND THE SUBAERIAL TRANSMIGRATION, by A. H. Church. rgig. Pp. 95. 3s. 6 . net.

4. ELEMENTARY NOTES ON STRUCTURAL BOTANY, by $\Lambda$. H. Church. I9I9. I2 Lecture-schedules. Pp. 27. 2s. net.

5. ELEMENTARY NOTES ON THE REPRODUCTION OF ANGIOSPERMS, by A. H. CHURCH. I9Ig. Io Lecture-schedules. Pp. 24 .

2s, net.

6. ON THE INTERPRETATION OF PHENOINENA OF PHYLLOTAXIS, by A. H. С HURCH. 1920. Pp. 58, I8 figs.

3s. $6 d$. net.

7. ELEMENTARY NOTES ON THE MORPHOLOGY OF FUNGI, by A. H. Church. I920. I3 Lecture-schedules. Pp. 29. 2s. net.

8. ELEMENTARY NOTES ON CONIFERS. By A. H. CHURCH. I920. Fifteen Lecture and Laboratory Schedules. Pp. 32. 2.s. net.

9. FORM.FACTORS IN CONIFERAE. By A. H. CiUUrCH. I9zo.

Arranged as Supplement to preceding. Pp. $28 . \quad 2 s$. net. 



